\title{
Effects of the Mount Pinatubo Eruption on Solar Insolation: Four Case Studies
}

\author{
Andrew L. Rosenthal and Jeffrey M. Robert \\ New Mexico State University \\ Southwest Technology Development institute \\ P.O. Box 30001/Dept. 3SOL \\ Las Cruces, New Mexico 88003-0001
}

\begin{abstract}
The Southwest Technology Development Institute staff analyzed solar insolation data from four sites in the western United States recorded during the years 1990 through 1992. Analyses were performed to identify and quantify the effects on insolation caused by the eruption of Mount Pinatubo in the Philippines on June 15th and 16th 1991. Data from each of the sites were recorded by dedicated datalogging equipment. Every effort was made to prevent data acquisistion system problems (e.g., drift of the datalogger clock) from influencing the accuracy of the results.
\end{abstract}




\section{ACKNOWLEDGMENTS}

Thanks are extended to the following persons and organizations for making essential data available for use in this report:

- Ms. Vanessa Morris and the Pacific Gas and Electric Company for their contribution of the data from Carrisa Plains, California;

- Mr. Bill Marion and the National Renewable Energy Laboratory for their contribution of the data from Golden, Colorado. 


\section{TABLE OF CONTENTS}

Section

Page\#

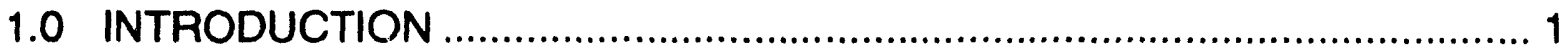

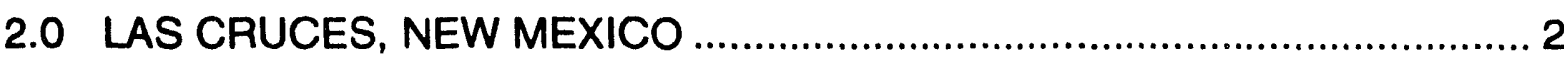

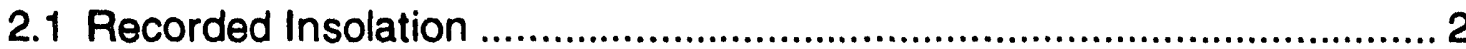

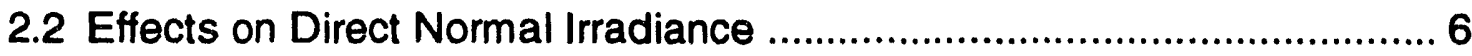

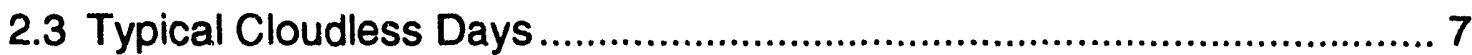

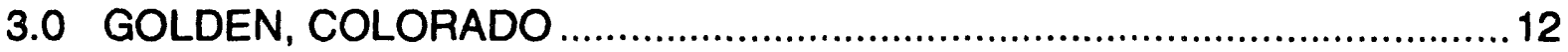

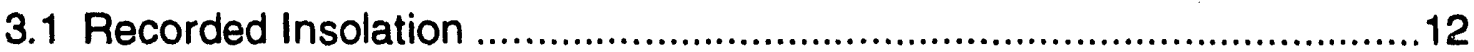

3.2 Effects on Direct Normal Irradiance .................................................16

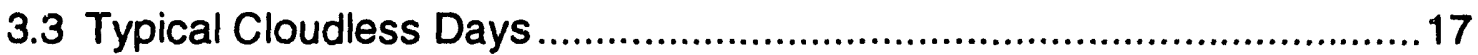

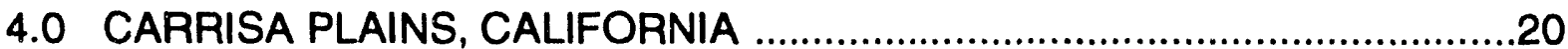

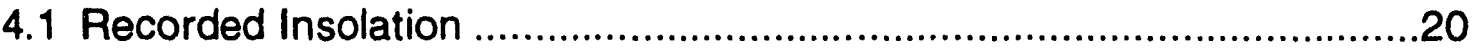

4.2 Effects on Direct Normal Irradiance ....................................................24

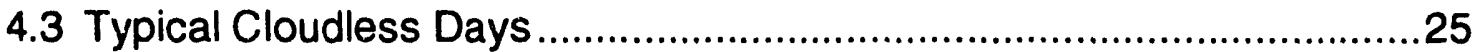

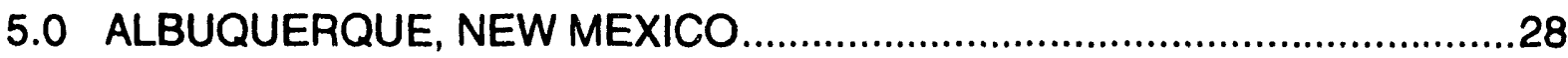

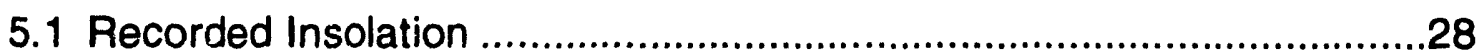

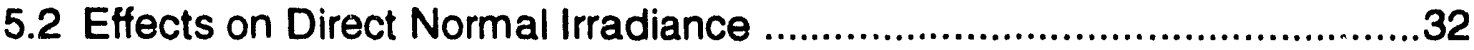

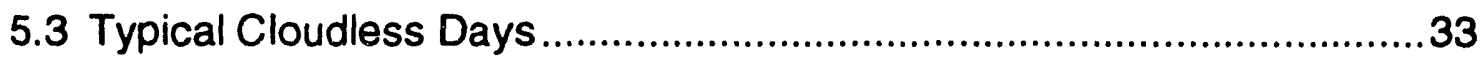

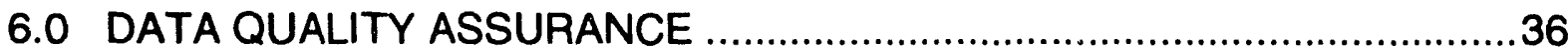

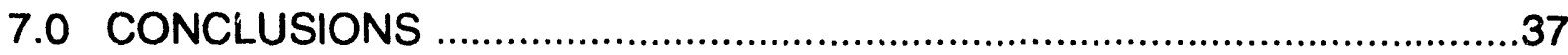

SUMMARY

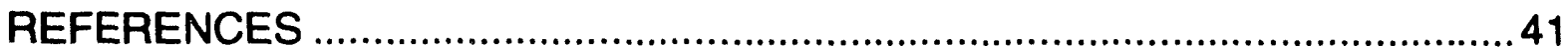




\section{TABLES}

Table

Pace\#

Table 2-1. Direct Normal Insolation for Las Cruces, New Mexico........................ 2

Table 2-2. Global Horizontal Insolation for Las Cruces: New Mexico .................. 3

Table 3-1. Direct Normal Insolation for Golden, Colorado .................................12

Table 3-2. Global Horizontal Insolation for Golden, Colorado.......................... 13

Table 4-1. Direct Normal Insolation of Carrisa Plains, California ........................20

Table 4-2. Global Horizontal Insolation for Carrisa Plains, California .................21

Table 5-1. Direct Normal Insolation for Albuquerque, New Mexico ....................28

Table 5-2. Global Horizontal Insolation for Albuquerque, New Mexico ...............29

\section{FIGURES}

Figure

Page \#

Figure 2-1. Direct Normal Irradiance -- Las Cruces, New Mexico ….................. 4

Figure 2-2. Global Horizontal Irradiance -- Las Cruces, New Mexico.................. 5

Figure 2-3. Daily DNI Ratios -- Las Cruces, New Mexico ................................... 6

Figure 2-4. Direct Normal and Diffuse Irradiance -- Las Cruces, New Mexico... 9

Figure 2-5. Global Horizontal Irradiance -- Las Cruces, New Mexico................. 9

Figure 2-6. Direct Normal and Diffuse Irradiance -- Las Cruces, New Mexico.. 10

Figure 2-7. Global Horizontal Irradiance -- Las Cruces, New Mexico................. 10

Figure 2-8. Direct Normal and Diffuse Irradiance -- Las Cruces, New Mexico.. 11

Figure 2-9. Global Horizontal Irradiance -- Las Cruces, New Mexico................ 11

Figure 3-1. Direct Normal Irradiance -- Golden, Colorado ................................ 14

Figure 3-2. Global Horizontal Irradiance -- Golden, Colorado ..........................15 


\section{FIGURES - CONTINUED}

Figure

Page\#

Figure 3-3. Daily DNI Ratios -- Golden, Colorado ..........................................16

Figure 3-4. Direct Normal and Diffuse Irradiance -- Golden, Colorado .............18

Figure 3-5. Global Horizontal Irradiance -- Golden, Colorado ......................... 18

Figure 3-6. Direct Normal and Diffuse Irradiance -- Golden, Colorado .............19

Figure 3-7. Global Horizontal Irradiance -- Golden, Colorado .......................... 19

Figure 4-1. Direct Normal Irradiance -- Carrisa Plains, California .....................22

Figure 4-2. Global Horizontal Irradiance -- Carrisa Plains, California ................23

Figure 4-3. Daily DNI Ratios -- Carrisa Plains, California .................................24

Figure 4-4. Direct Normal and Diffuse Irradiance -- Carrisa Plains, California .. 26

Figure 4-5. Global Horizontal Irradiance -- Carrisa Plains, California ...............26

Figure 4-6. Direct Normal and Diffuse Irradiance -- Carrisa Plains, California ..27

Figure 4-7. Global Horizontal Irradiance -- Carrisa Plains, California ................27

Figure 5-1. Direct Normal Irradiance -- Albuquerque, New Mexico ....................30

Figure 5-2. Global Horizontal Irradiance -- Albuquerque, New Mexico ..............31

Figure 5-3. Daily DNI Ratios -- Albuquerque, New Mexico ...............................32

Figure 5-4. Direct Normal and Diffuse Irradiance -- Albuquerque, New Mexico 34

Figure 5-5. Global Horizontal Irradiance -- Albuquerque, New Mexico ..............34

Figure 5-6. Direct Normal and Diffuse Irradiance -- Albuquerque, New Mexico 35

Figure 5-7. Global Horizontal Irradiance -- Albuquerque, New Mexico ..............35

Figure S-1. Normalized Clear Sky DNI -- Las Cruces, New Mexico ...................39

Figure S-2. Normalized Clear Sky DNI .- Golden, Colorado .............................39 


\subsection{INTRODUCTION}

The explosion of Mount Pinatubo in the Philippines on June 15 and 16, 1991, was the largest volcanic eruption of this century. By most accounts $(1,2,3)$ Pinatubo ejected 15 to $\mathbf{2 0}$ million tons of ash and sulfur dioxide 23 kilometers into the stratosphere. Satellite photographs taken 21 days after the eruption show a wide belt of these contaminants encircling the globe between $25^{\circ} \mathrm{North}$ and $20^{\circ}$ South latitude (1). Volcanic ash generally settles out of the atmosphere within weeks or months of an eruption. The sulfur dioxide gas mixes with moisture to become aerosol droplets of sulfuric acid that can remain in the stratosphere for several years. These aerosols scatter solar radiation in the visible wavelengths, $.58-.69$ micrometers (1).

This report examines data recorded at four locations in the western United States to assess the effects of the Pinatubo eruption on solar insolation levels at these sites. The four monitoring stations that supplied the raw data for this report were:

- The Southwest Region Experiment Station in Las Cruces, New Mexico;

- The Solar Radiation Research Laboratory at the National Renewable Energy Laboratory in Golden, Colorado;

- The Solar Insolation Monitor Program station operated by the Pacific Gas and Electric Company in Carrisa Plains, California;

- The Solar Insolation monitor station at Sandia National Laboratories in Albuquerque, New Mexico.

Data from the four sites are presented below in Sections 2 through 5 . Section 6 discusses the data quality assurance procedures that were followed in the preparation of this report. 


\subsection{LAS CRUCES. NEW MEXICO}

Solar resource data have been recorded at the Southwest Region Experiment Station (SWRES) in Las Cruces, New Mexico, since the early 1980s. The site is in the Rio Grande valley in the south-central region of the state. The longitude and latitude of the location are $\mathrm{W} 106.74^{\circ}$ and $\mathrm{N} 32.27^{\circ}$. The elevation is 1200 meters (3940 feet). On site is an Eppley Normal Incidence Pyrheliometer (NIP) to measure direct normal irradiance, and an Eppley Precision Spectral Pyranometer (PSP) to measure global horizontal irradiance. An Eppley shadow band and PSP have been in use since April 1991 to measure horizontal diffuse irradiance.

\subsection{Recorded Insolation}

Table 2-1 presents the direct normal insolation recorded in Las Cruces for the period of January 1990 through December 1992.

Table 2-1

Direct Normal Insolation for Las Cruces, New Mexico: 1990 - 1992

$\begin{array}{lccc}\text { Month } & \begin{array}{c}1990 \\ \left(\mathrm{kWh} / \mathrm{m}^{2}\right)\end{array} & \begin{array}{c}1991 \\ \left(\mathrm{kWh} / \mathrm{m}^{2}\right)\end{array} & \begin{array}{c}1992 \\ \left(\mathrm{kWh} / \mathrm{m}^{2}\right)\end{array} \\ \text { January } & 194.8 & 155.4 & 97.4 \\ \text { February } & 189.0 & 147.2 & 98.7 \\ \text { March } & 204.9 & 207.8 & 168.7 \\ \text { April } & 246.8 & 270.3 & 230.6 \\ \text { May } & 267.1 & 294.4 & 162.3 \\ \text { June } & 251.3 & 263.8 & 251.1 \\ \text { July } & 204.0 & 164.1 & 227.2 \\ \text { August } & 187.2 & 194.0 & 201.1 \\ \text { September } & 177.6 & 160.1 & 214.3 \\ \text { October } & 255.4 & 211.3 & 1 \\ \text { November } & 190.3 & 174.0 & 166.8 \\ \text { December } & 192.4 & 110.5 & 90.7\end{array}$

1 The NIP was off-line for calibration during October 1992, and data are unavailable.

Table 2-2 presents the global horizontal insolation recorded in Las Cruces during the same three-year period. These tables are presented to provide a baseline of information only. Monthly insolation totals alone cannot be used to assess the effects of the Pinatubo eruption. Ordinary weather variations may change the ratio of clear to cloudy days, giving rise to differences up to $15 \%$ in the monthly insolation totals observed from one year to another. 
Table 2-2

Global Horizontal Insolation for Las Cruces, New Mexico: 1990 - 1992

$\begin{array}{lccc}\text { Month } & \begin{array}{c}1990 \\ \left(\mathrm{kWh} / \mathrm{m}^{2}\right)\end{array} & \begin{array}{c}1991 \\ \left(\mathrm{kWh} / \mathrm{m}^{2}\right)\end{array} & \begin{array}{c}1992 \\ \left(\mathrm{kWh} / \mathrm{m}^{2}\right)\end{array} \\ \text { January } & 106.9 & 96.23 & 90.7 \\ \text { February } & 133.5 & 109.2 & 110.4 \\ \text { March } & 171.9 & 176.8 & 170.6 \\ \text { April } & 207.0 & 223.5 & 213.5 \\ \text { May } & 235.8 & 244.8 & 204.5 \\ \text { June } & 229.6 & 225.0 & 233.4 \\ \text { July } & 211.7 & 196.0 & 227.4 \\ \text { August } & 196.2 & 197.1 & 201.2 \\ \text { September } & 159.7 & 155.0 & 182.3 \\ \text { October } & 156.5 & 154.5 & 146.5 \\ \text { November } & 107.7 & 107.1 & 106.6 \\ \text { December } & 99.0 & 79.2 & 74.7\end{array}$

Figure 2-1 shows the Direct Normal Irradiance (DNI) recorded over the three-year period. Two data points are plotted for each day: the hourly average value recorded for the period from $11: 00 \mathrm{am}$ to $12: 00 \mathrm{pm}$, and the hourly average value recorded for the period from 12:00 pm to 1:00 pm. Solar noon does not coincide with local clock time, but will fall within one of these two hourly periods throughout the year.

Figure 2-1 illustrates some of the effects of the Pinatubo eruption. The 1990 DNI data show a pattern typical of years prior to the volcano's eruption: a cycle of winter highs and summer lows. The high winter values, occurring when the sun is near perihelion, often exceeded $1000 \mathrm{~W} / \mathrm{m}^{2}$. The summer values, lower as a result of the increased Earth-Sun distance and increased atmospheric moisture, reached approximately 950 $\mathrm{W} / \mathrm{m}^{2}$. Following the Pinatubo eruption in June 1991, this cycle was disrupted. During the winter of $1991 / 92$, DNI values did not surpass $1000 \mathrm{~W} / \mathrm{m}^{2}$, nor have they since the eruption.

Figure 2-2 shows the Global Horizontal Irradiance (GHI) recorded for the three-year period. Again, the two hourly records that bracket solar noon are plotted for each day. 


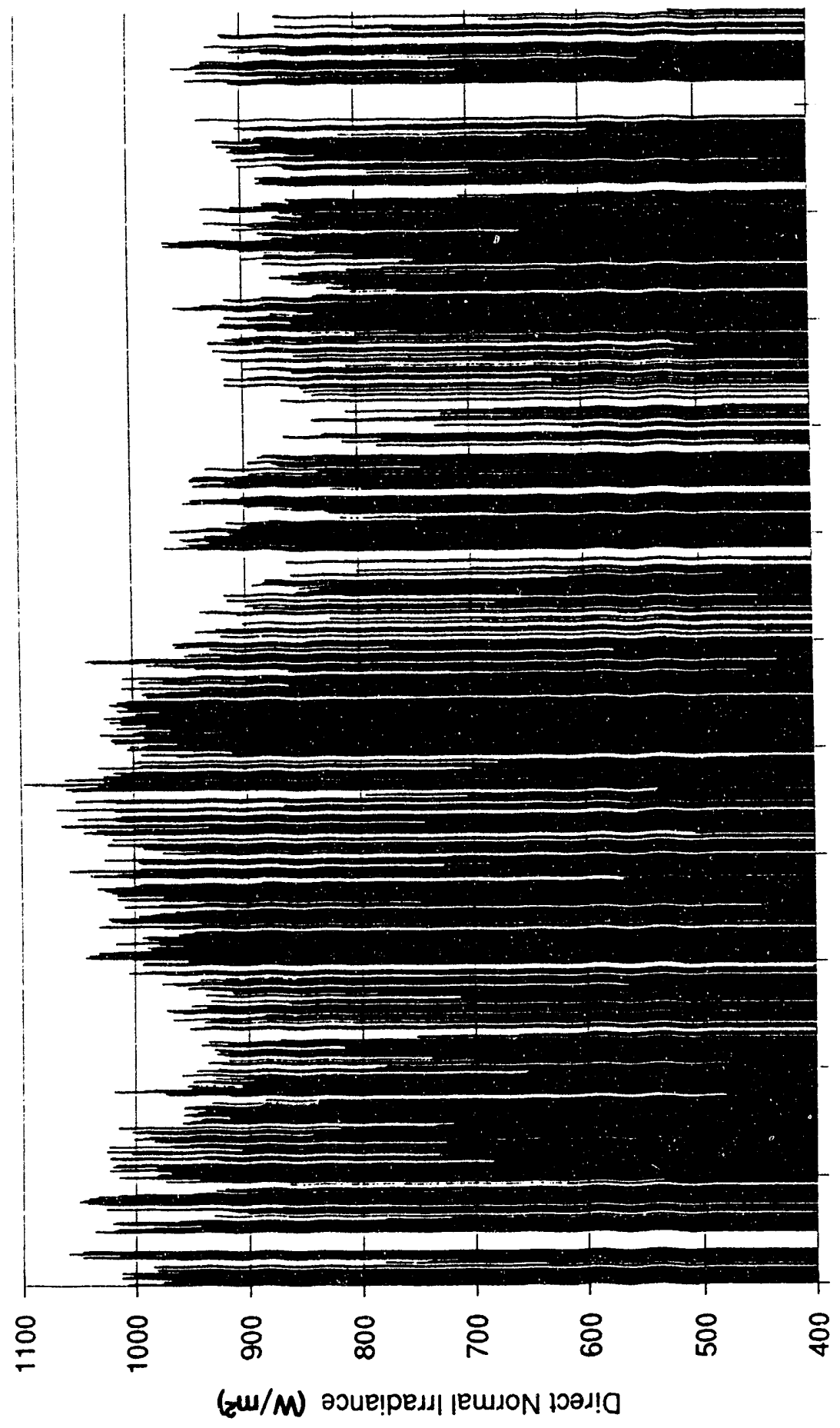

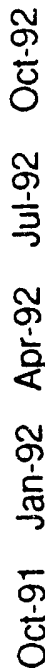

$\frac{\overline{5}}{5}$

क़

高

- ॠ

宽

온

을

Z

ฮ 동

产

○

क्ष

$\overline{3}$

오

高

ஸे

인

号

피

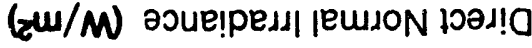




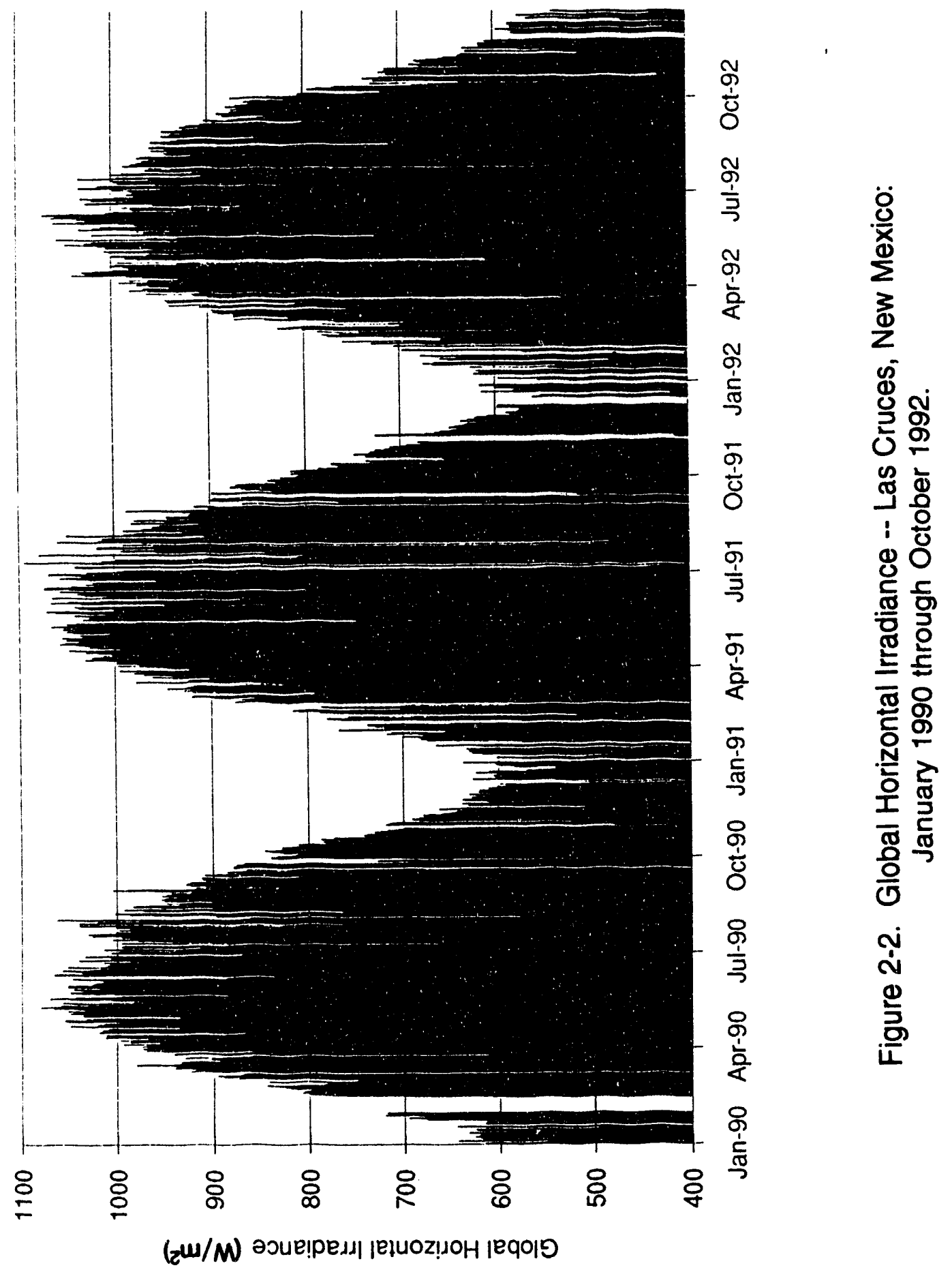


The typical GHI yearly cycle shows higher values in the summer when the midday sun travels close to normal incidence to the horizontal pyranometer, and lower values in the winter when the noon sun remains lower in the southern sky. In general, the 1992 summer values are lower than those recorded in the two previous years, with some exceptions. Overall, the eruption has had less effect on the global horizontal irradiance than on the direct normal irradiance.

\subsection{Effects on Direct Normal Irradiance}

Figure 2-3 presents a qualitative illustration of the effects of the eruption on DNI levels recorded in Las Cruces, New Mexico. The figure shows daily quotients of 1991 vs. 1990 and 1992 vs. 1990 'clear sky' DNI values. The method used to screen for clear sky conditions extracted, for each day of the year, the single maximum DNI value observed during a 15-day period. That is, for day $n$, the value used was the maximum DNI observed in the period of day $n-7$ to day $n+7$. Quotients were generated by dividing the extracted value for each day of 1991 and 1992 by its corresponding 1990 value. In this way, the 1991 and 1992 data were indexed against pre-eruption (1990) conditions. Figure 2-3 shows these 'clear sky' DNI ratios determined for Las Cruces, New Mexico. While this method can not be construed as a purely quantitative comparison, it serves to illustrate the effects of the eruption on recorded DNI levels.

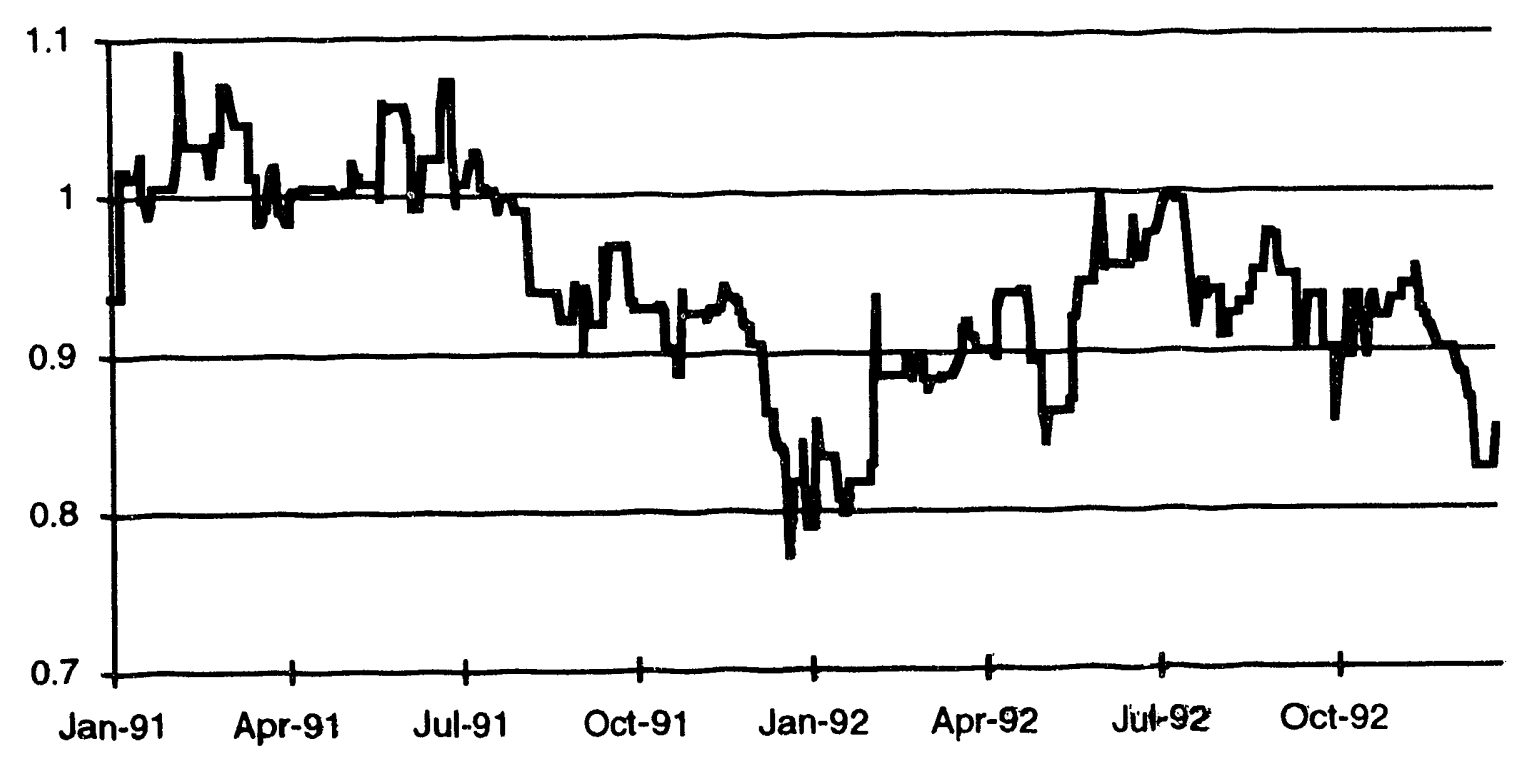

Figure 2-3. Clear Sky DNI Quotients -- Las Cruces, NM 1991/1990 and 1992/1990. 
Prior to the eruption, 1991 clear sky DNI values were comparable to those recorded in 1990. The ratios for this period are approximately equal to 1.0. Following the eruption, clear sky DNI values declined. During December 1991 and January 1992, DNI values fell to approximately $80 \%$ of their 1990 levels.

During spring and summer 1992, the effects of the eruption moderated. Clear sky DNI levels recorded during June/July 1992 were within a few percent of historical (1990) levels. At year's end, however, the effects of the eruption again became more pronounced. Clear sky DNI levels dropped to less than $90 \%$ of their 1990 levels.

\subsection{Typical Cloudless Days}

The data were examined to select days that had been cloudless or near cloudless in each of the three years of the reporting period. Three sets of these days are presented here.

Figure 2-4 shows DNI and diffuse irradiance data recorded during individual days in February of three consecutive years: February 16, 1990; February 14, 1991; and February 14, 1992. In this case, the 1990 and 1991 data were recorded prior to the eruption. The diffuse data for 1990 and 1991 have been calculated. Figure 2-5 shows the $\mathrm{GHI}$ data recorded during these three days.

As shown in Figure 2-4, the DNI levels recorded during 1990 and 1991 were comparable. The 1992 levels show attenuation resulting from the eruption. Expressed on a percentage basis, the DNI was down $12 \%\left(125 \mathrm{~W} / \mathrm{m}^{2}\right)$ in 1992 compared with 1990. Conversely, the 1992 diffuse data show an increase of approximately $50 \%$ (40 $\mathrm{W} / \mathrm{m}^{2}$ ) when compared with 1990.

Figure 2-6 shows the DNI and diffuse data recorded during July 17, 1990; July 17, 1991; and July 16, 1992 . Figure 2-7 shows the GHI data recorded during these three days. As noted earlier, the effects of the volcano diminished during the summer months of 1992. The midday DNI values recorded during all three years were within $3 \%$. The recorded diffuse data also show little difference over the three-year period.

Figure 2-8 shows the DNI and diffuse data recorded on December 11, 1990; December 12, 1991; and December 9, 1992. Figure 2-9 shows the GHI data recorded during these three days. Figure 2-8 illustrates the first-year and the second-year effects of the 
eruption. The 1991 DNI value, recorded six months after the eruption, shows a decline of $18 \%\left(125 \mathrm{~W} / \mathrm{m}^{2}\right)$ when compared with 1990 . In comparison, the 1992 value, recorded 18 months following the eruption, shows a decline of only $8 \%\left(79 \mathrm{~W} / \mathrm{m}^{2}\right)$ compared with 1990 levels. 


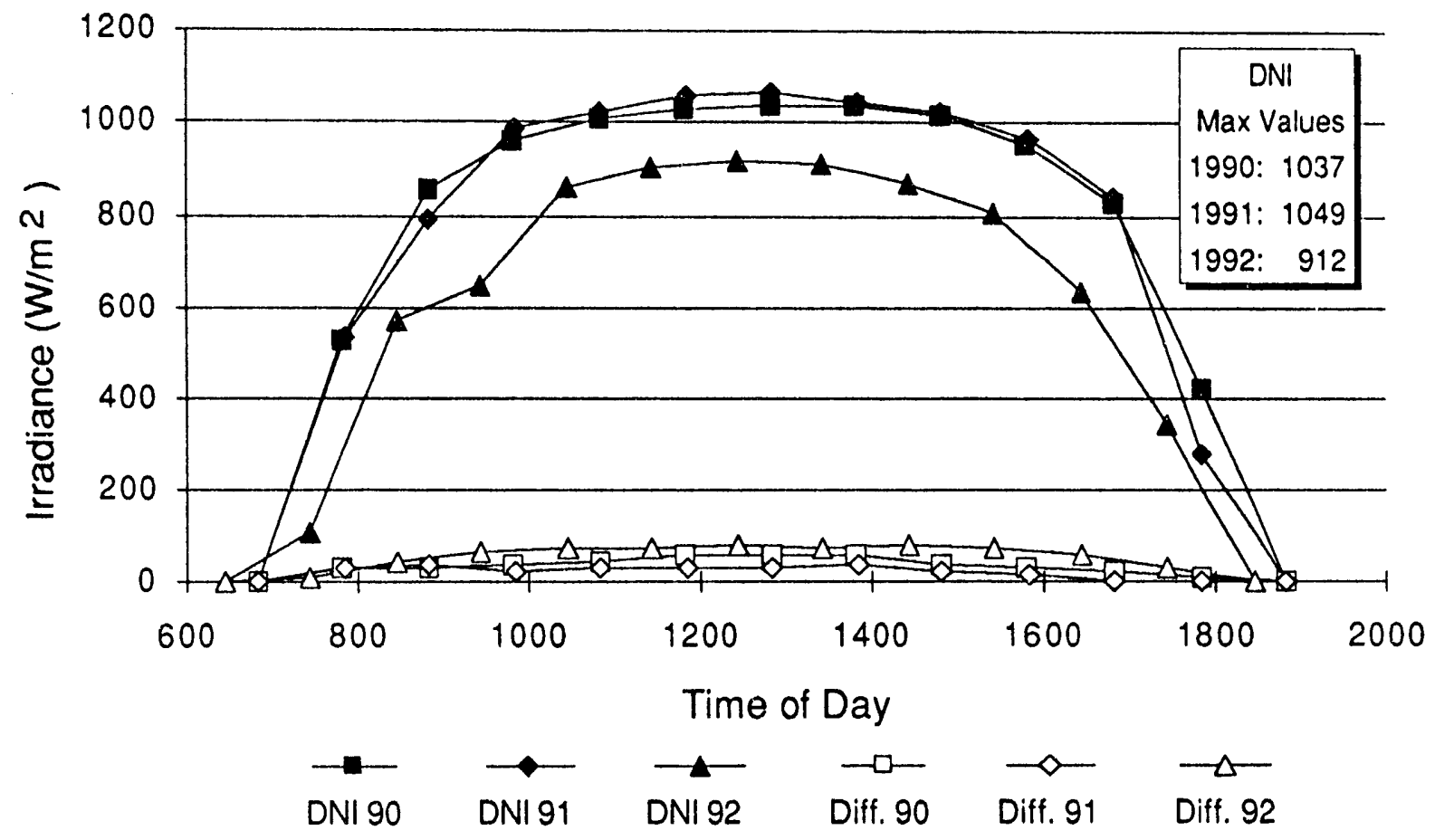

Figure 2-4. Direct Normal and Diffuse Irradiance -- Las Cruces, New Mexico 2/16/90, 2/14/91, 2/14/92.

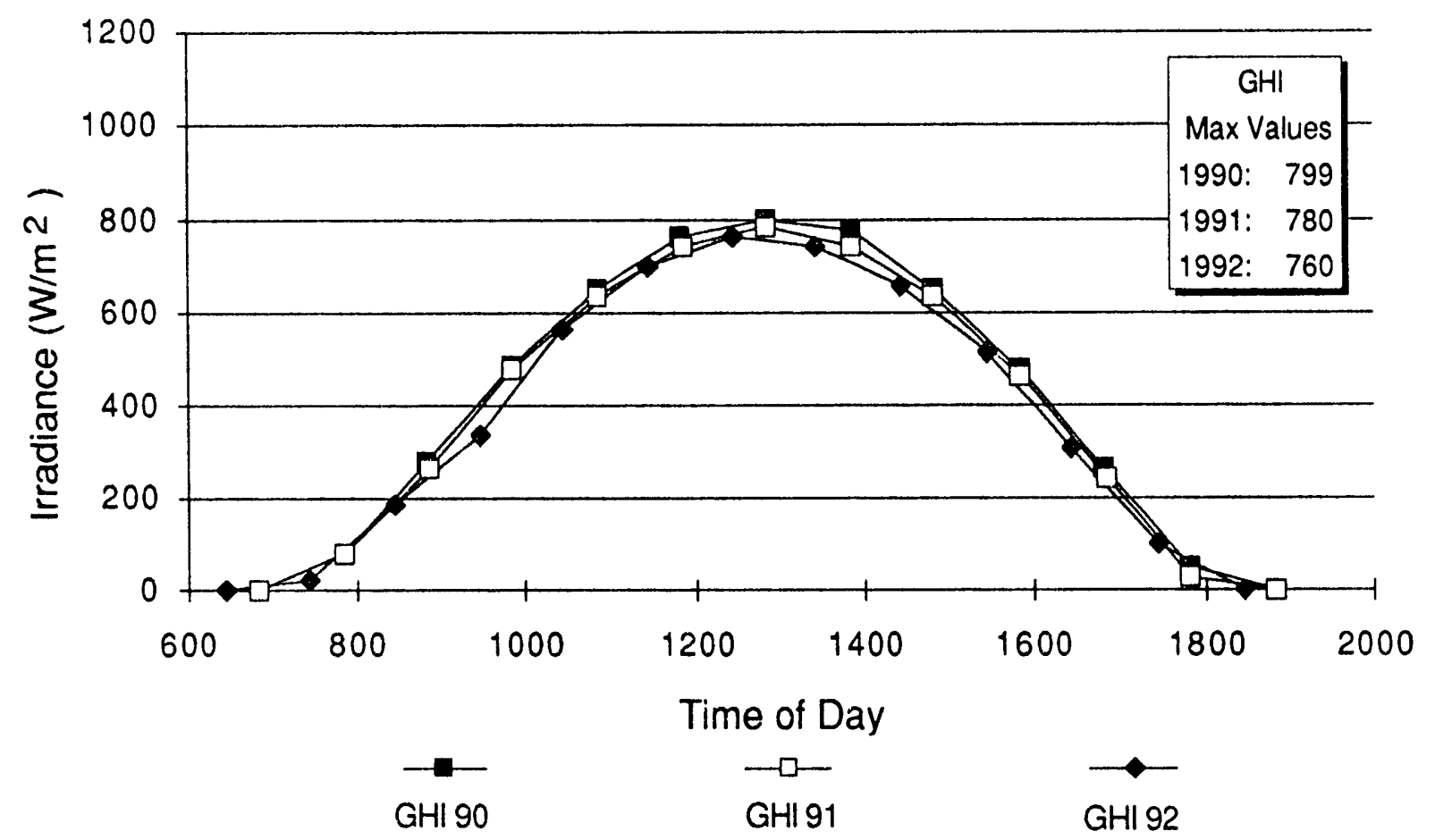

Figure 2-5. Global Horizontal Irradiance -- Las Cruces, New Mexico 2/16/90, 2/14/91, 2/14/92. 


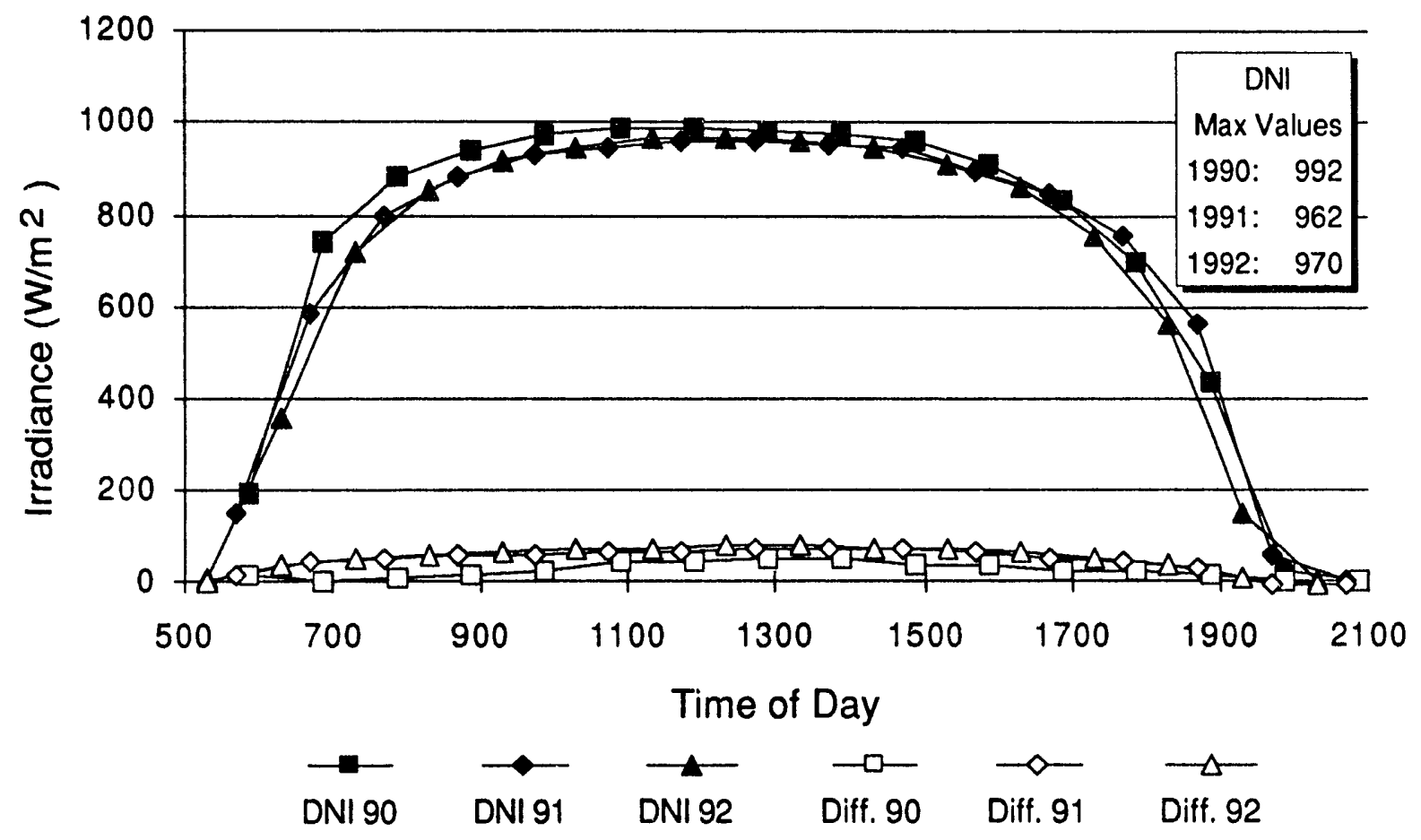

Figure 2-6. Direct Normal and Diffuse Irradiance -- Las Cruces, New Mexico $7 / 17 / 90,7 / 17 / 91,7 / 16 / 92$.

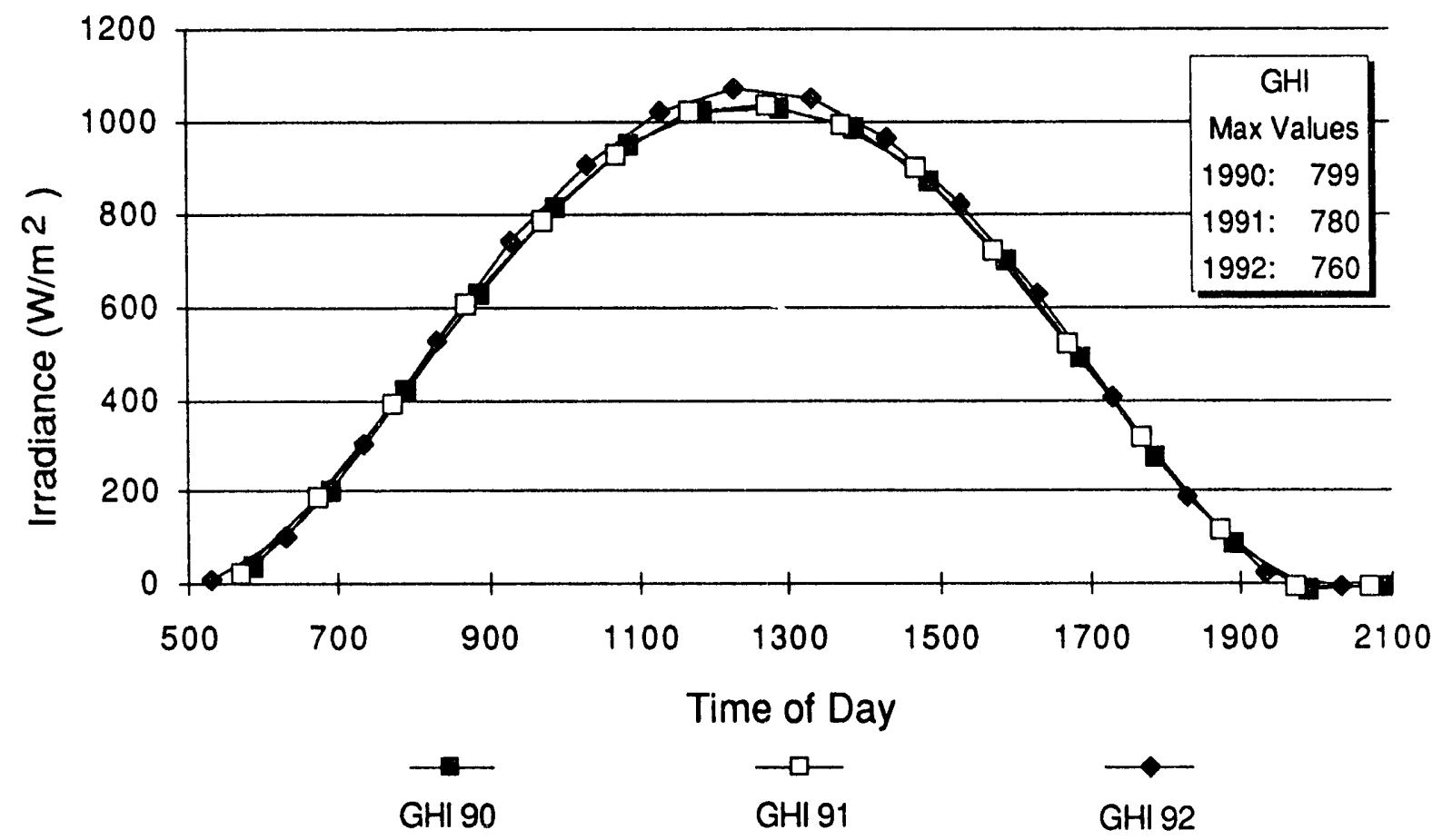

Figure 2-7. Global Horizontal Irradiance -- Las Cruces, New Mexico 7/17/90, 7/17/91, 7/16/92. 


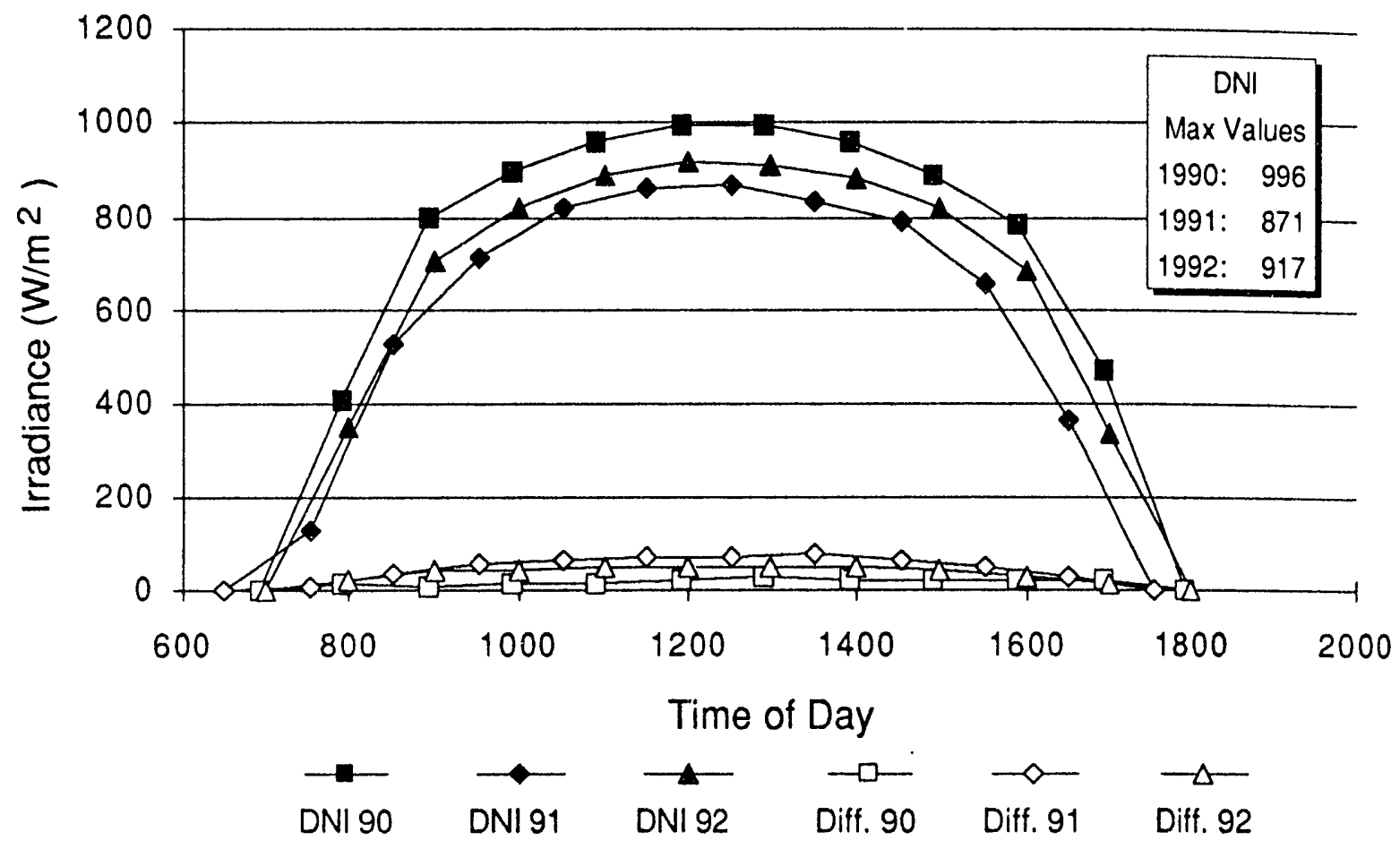

Figure 2-8. Direct Normal and Diffuse Irradiance -- Las Cruces, New Mexico $12 / 11 / 90,12 / 12 / 91,12 / 9 / 92$.

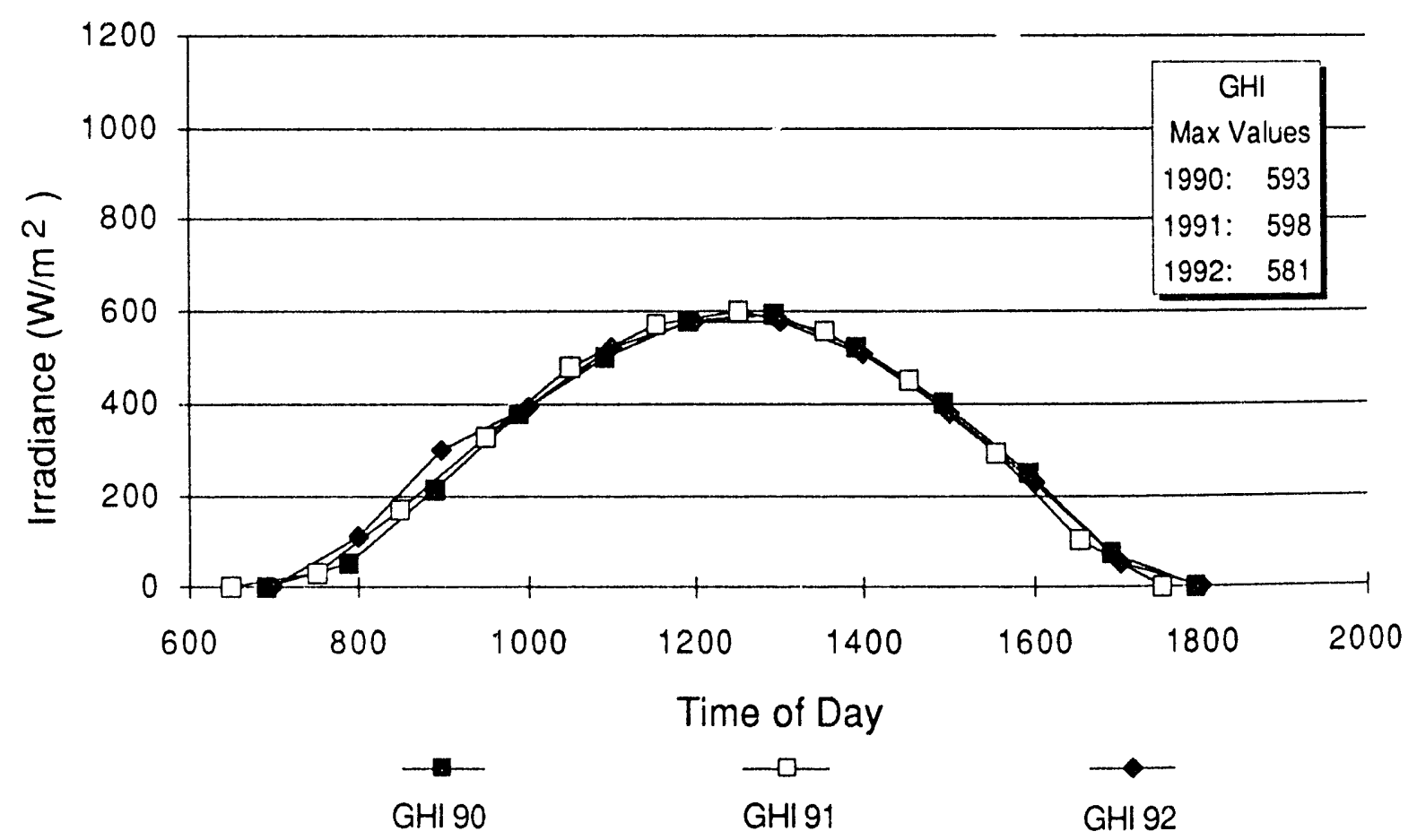

Figure 2-9. Global Horizontal Irradiance -- Las Cruces, New Mexico 12/11/90, 12/12/91, 12/9/92. 


\subsection{GOLDEN, COLORAR?}

The National Renewable Energy Laboratory (NREL) has been collecting solar and meteorological data at the Solar Radiation Research Laboratory (SRRL) in Golden, Colorado, since 1981. The site was originally located at the base of South Table Mountain but was moved to the top of the mountain in 1983. The longitude and latitude of the location are $W 105.18^{\circ}$ and $N 39.74^{\circ}$. The elevation is 1829 meters (6000 feet). Approximately 25 solar and meteorological instruments are in use at the site. This report makes use of data from three of these instruments: an Eppley Normal Incidence Pyrheliometer (NIP) to measure direct normal irradiance; an Eppley Precision Spectral Pyranometer (PSP) to measure global horizontal irradiance; and an Eppley shadow band and PSP to measure horizontal diffuse irradiance.

\subsection{Recorded Insolation}

Table 3-1 presents the direct normal insolation recorded in Golden for the period of January 1990 through November 1992. In this reporting period, 35 events were experienced during which data from the NIP were unavailable. The longest of these was the period of March 28, 1992 through April 27, 1992 when the NIP was off-line for recalibration.

Table 3-1

Direct Normal Insolation for Golden, Colorado: 1990 - 1992

$\begin{array}{lccc}\text { Month } & \begin{array}{c}1990 \\ \left(\mathrm{kWh} / \mathrm{m}^{2}\right)\end{array} & \begin{array}{c}1991 \\ \left(\mathrm{kWh} / \mathrm{m}^{2}\right)\end{array} & \begin{array}{c}1992 \\ \left(\mathrm{kWh} / \mathrm{m}^{2}\right)\end{array} \\ \text { January } & 172.0 & 149.4 & 132.5 \\ \text { February } & 135.1 & 141.0 & 110.8 \\ \text { March } & 131.9 & 194.4 & 107.1 \\ \text { April } & 119.5 & 129.5 & 1 \\ \text { May } & 180.2 & 166.7 & 131.0 \\ \text { June } & 249.0 & 181.0 & 164.2 \\ \text { July } & 160.3 & 208.0 & 172.6 \\ \text { August } & 192.0 & 166.0 & 139.0 \\ \text { September } & 186.4 & 174.1 & 196.8 \\ \text { October } & 191.8 & 171.1 & 134.0 \\ \text { November } & 142.9 & 119.0 & 91.3 \\ \text { December } & 157.2 & 123.4 & -\end{array}$

1 The NIP was off-line for calibration during most of April 1992, and data are unavailable. 
Table 3-2 presents the global horizontal insolation recorded in Golden during the same three-year period. As stated earlier, tables of monthly insolation totals alone cannot be used to assess the effects of the Pinatubo eruption.

\section{Table 3-2}

Global Horizontal Insolation for Golden, Colorado: 1990 - 1992

$\begin{array}{lccc}\text { Month } & \begin{array}{c}1990 \\ \left(\mathrm{kWh} / \mathrm{m}^{2}\right)\end{array} & \begin{array}{c}1991 \\ \left(\mathrm{kWh} / \mathrm{m}^{2}\right)\end{array} & \begin{array}{c}1992 \\ \left(\mathrm{kWh} / \mathrm{m}^{2}\right)\end{array} \\ \text { January } & 82.2 & 81.0 & 80.6 \\ \text { February } & 89.2 & 91.9 & 96.2 \\ \text { March } & 122.8 & 148.3 & 125.3 \\ \text { April } & 135.4 & 149.6 & 275.3 \\ \text { May } & 187.8 & 185.1 & 140.0 \\ \text { June } & 223.4 & 188.8 & 202.5 \\ \text { July } & 170.4 & 193.1 & 152.7 \\ \text { August } & 174.7 & 164.4 & 164.2 \\ \text { September } & 145.3 & 146.7 & 169.4 \\ \text { October } & 119.7 & 119.0 & 111.2 \\ \text { November } & 78.1 & 77.4 & 74.1 \\ \text { December } & 74.2 & 70.5 & -\end{array}$

Figure 3-1 shows the Direct Normal Irradiance (DNI) recorded over the period of January 1990 through November 1992. Two data points are plotted for each day: the hourly average value recorded for the period from 11:00 am to $12: 00 \mathrm{pm}$, and the hourly average value recorded for the period from 12:00 pm to 1:00 pm. Figure 3-2 shows the Global Horizontal Irradiance (GHI) recorded for the three-year period. Again, the two hourly records that bracket solar noon are plotted for each day.

The DNI data for Golden, Colorado, are similar to those recorded in Las Cruces, New Mexico (presented in Section 1). During 1990, a yearly cycle of winter highs and summer lows was observed. As in Las Cruces, winter highs exceeding $1000 \mathrm{~W} / \mathrm{m}^{2}$ were often recorded. During the summer of 1990, midday DNI levels decreased, reaching approximately $950 \mathrm{~W} / \mathrm{m}^{2}$. Following the Pinatubo eruption in June 1991, this cycle was altered. DNI values remained near $900 \mathrm{~W} / \mathrm{m}^{2}$ during the winter of $1991 / 92$ and during the last quarter of 1992. 


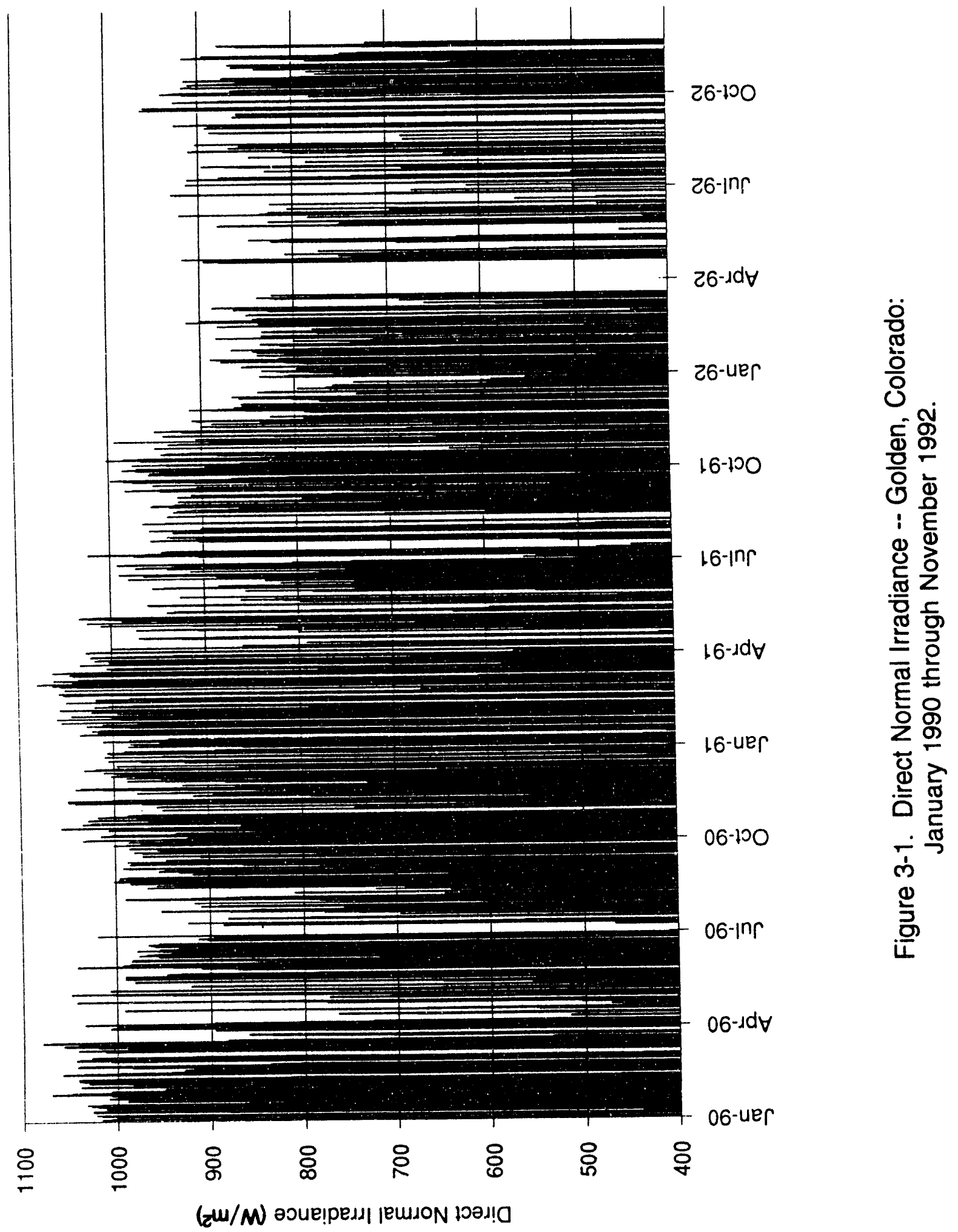




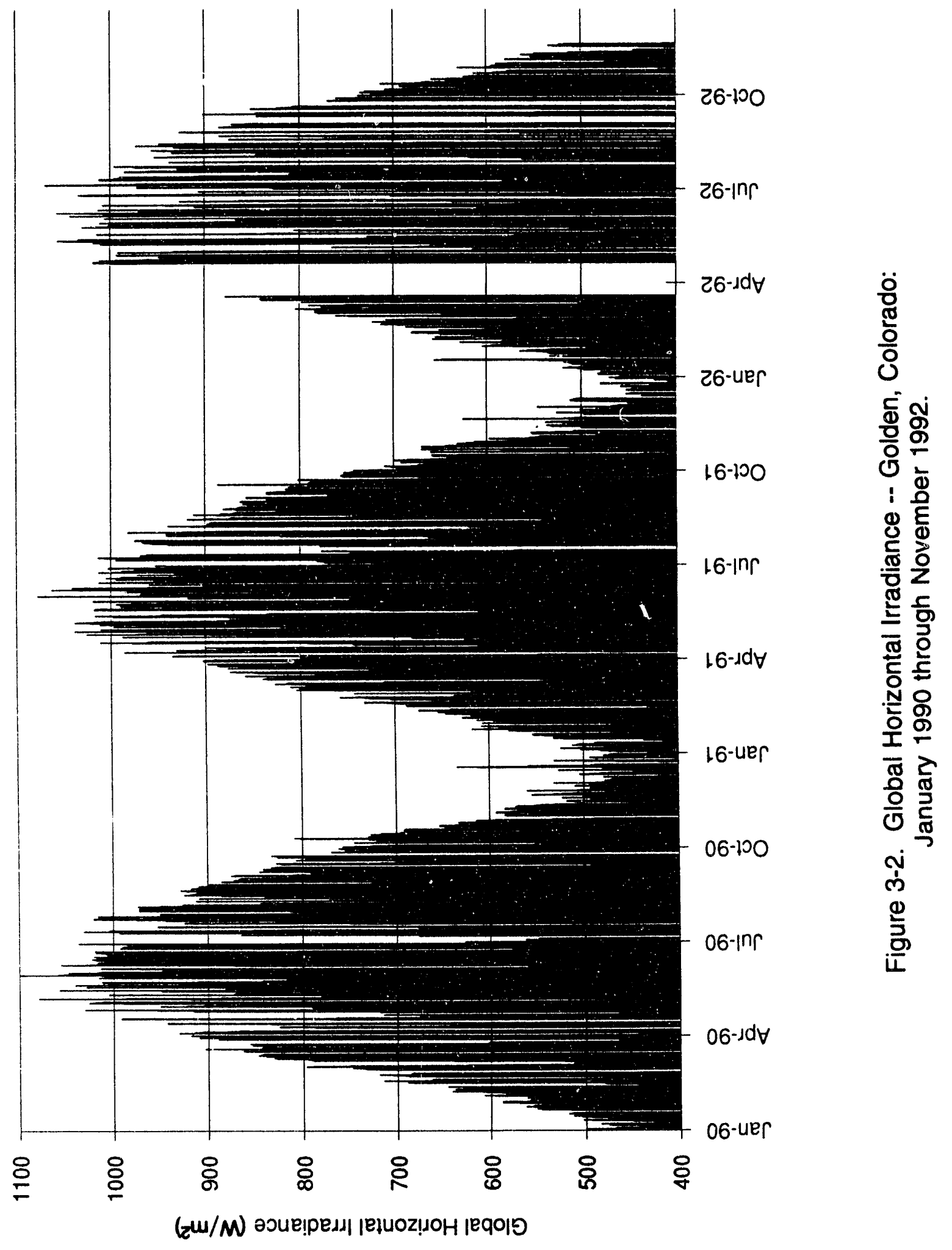




\subsection{Effects on Direct Normal Irradiance}

Figure 3-3 presents a qualitative illustration of the effects of the Pinatubo eruption on DNI levels recorded in Golden, Colorado. The figure shows daily quotients of 1991 vs. $19{ }^{\circ} 0$ and 1992 vs. 1990 'clear sky' DNI values. As outlined in the previous section, the method used to screen for clear sky conditions extracted, for each day of the year, the single maximum DNI value observed during a 15 -day period. That is, for day $n$, the value used was the maximum DNI observed in the period of day $n-7$ to day $n+7$. Quotients were generated by dividing the extracted value for each day of 1991 and 1992 by its corresponding 1990 value. In this way, the 1991 and 1992 data were indexed against pre-eruption (1990) conditions.

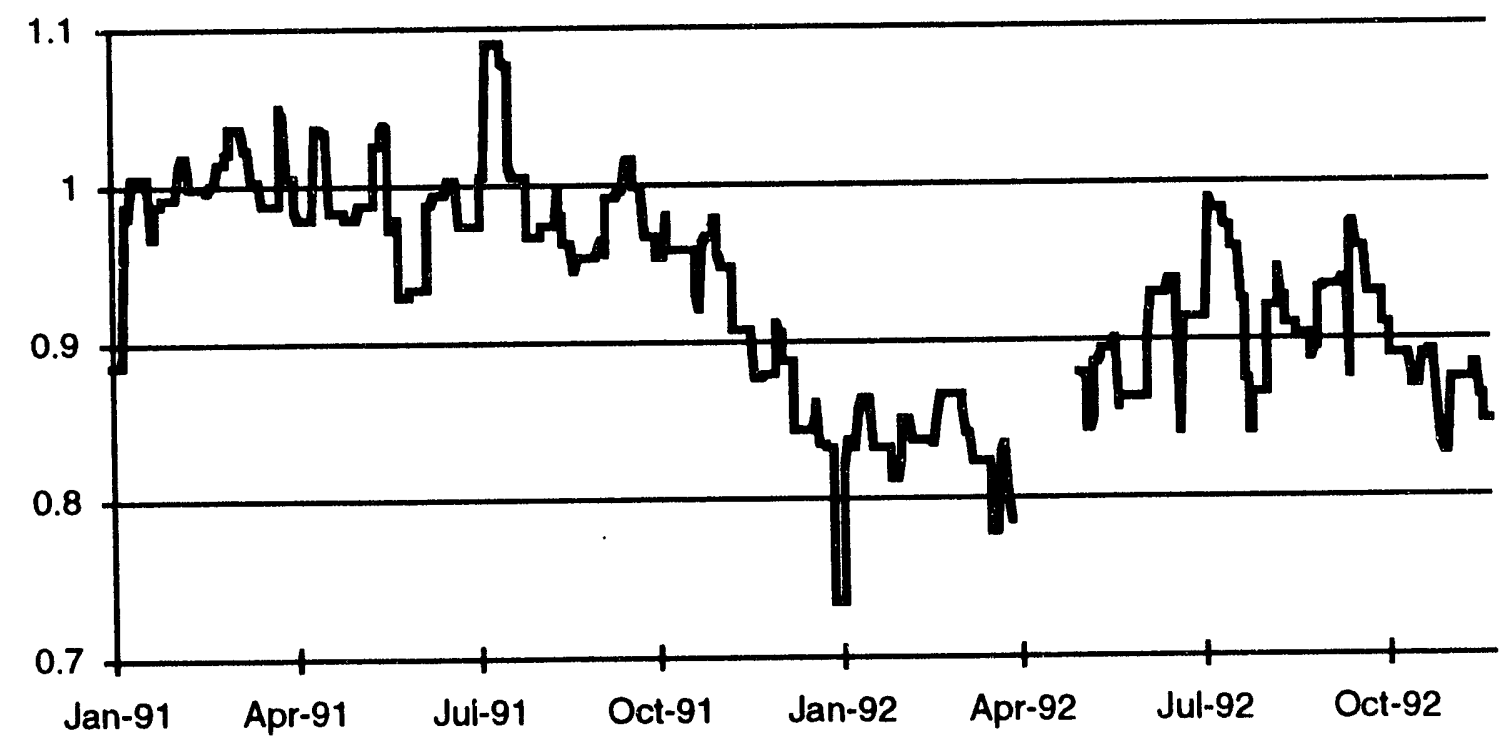

Figure 3-3. Clear Sky DNI Quotients -- Golden, CO 1991/1990 and 1992/1990.

Prior to the eruption, 1991 clear sky DNI values were unchanged from what they had been in 1990. Ratios of approximately 1.0 were determined for the first six months of 1991. Following the eruption, clear sky DNI values declined steadily. Minimum levels were recorded in January 1992 , when DNI values fell to approximately $85 \%$ of their 1990 levels. As observed elsewhere, the effects of the eruption abated during the summer months of 1992. Clear sky DNI levels returned to within a few percent of their 
1990 levels. At year's end, however, the effects of the eruption were again evident. At that time, clear sky DNI levels dropped to less than $90 \%$ of their recorded 1990 levels.

\subsection{Typical Cloudless Days}

The data were examined to select days that had been cloudless or near cloudless in each of the three years. Golden had fewer days that were cloudless in consecutive years than did the other sites evaluated in this report. Two sets of these days are presented here.

Figure 3-4 shows DNI and diffuse data recorded during individual days in either February or March of three consecutive years: March 2, 1990; March 7, 1991; and February 28, 1992. Figure 3-5 shows the GHI data recorded during these three days.

As shown in Figure 3-4, the DNI values for 1990 and the pre-eruption period of 1991 were comparable. In 1992, the recorded DNI data show attenuation resulting from the eruption. Expressed on a percentage basis, the DNI was dowr $2 \%\left(128 \mathrm{~W} / \mathrm{m}^{2}\right)$ in 1992 compared with 1990. The midday 1992 diffuse data show an increase of approximately $50 \mathrm{~W} / \mathrm{m}^{2}$ compared with 1990.

Figure 3-6 shows the DNI and diffuse data recorded during October 21, 1990; October 21, 1991; and October 10, 1992. Figure 3-7 shows the GHI data recorded during these three days. Figure 3-6 shows the first-year and the second-year effects of the eruption. The peak $1991 \mathrm{DNI}$ value $\left(943 \mathrm{~W} / \mathrm{m}^{2}\right)$, recorded four months after the eruption, is $9 \%$ lower than 1990 value $\left(1034 \mathrm{~W} / \mathrm{m}^{2}\right)$. The 1992 value $\left(917 \mathrm{~W} / \mathrm{m}^{2}\right)$, recorded 16 months following the eruption, shows a decline of $11 \%$ compared to 1990 levels. 


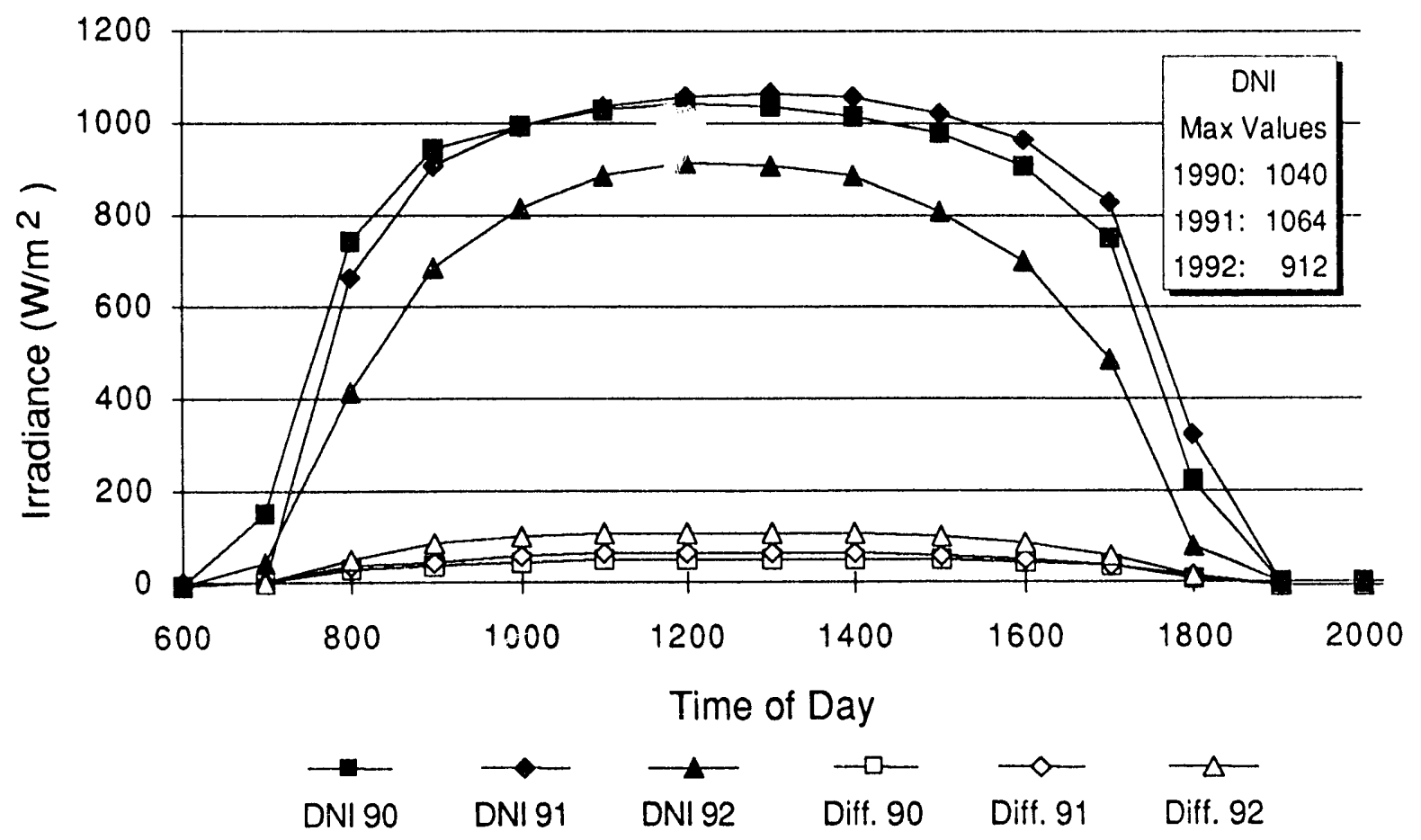

Figure 3-4. Direct Normal and Diffuse Irradiance -- Golden, Colorado $3 / 2 / 90,3 / 7 / 91,2 / 28 / 92$.

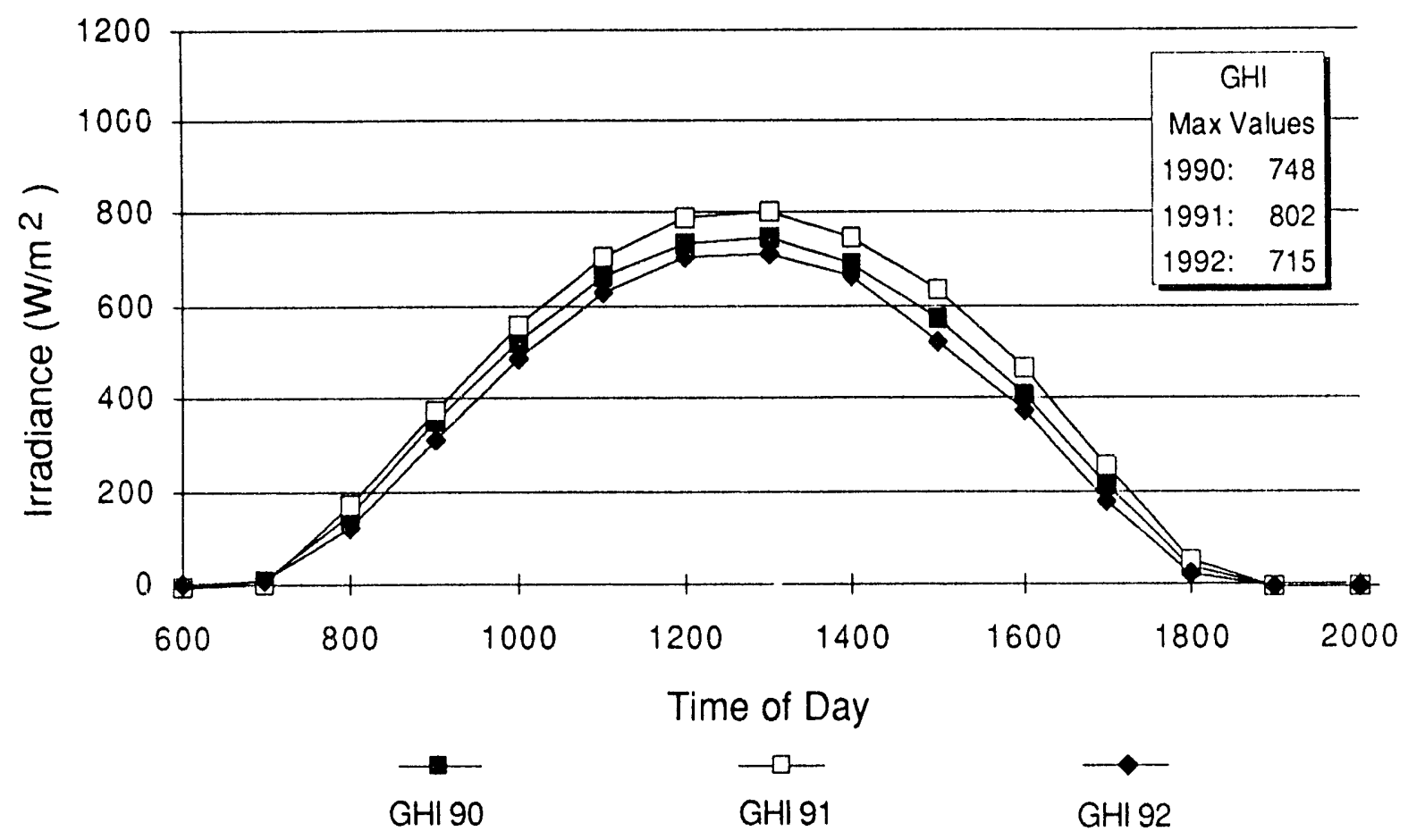

Figure 3-5. Global Horizontal Irradiance -- Golden, Colorado $3 / 2 / 90,3 / 7 / 91,2 / 28 / 92$. 

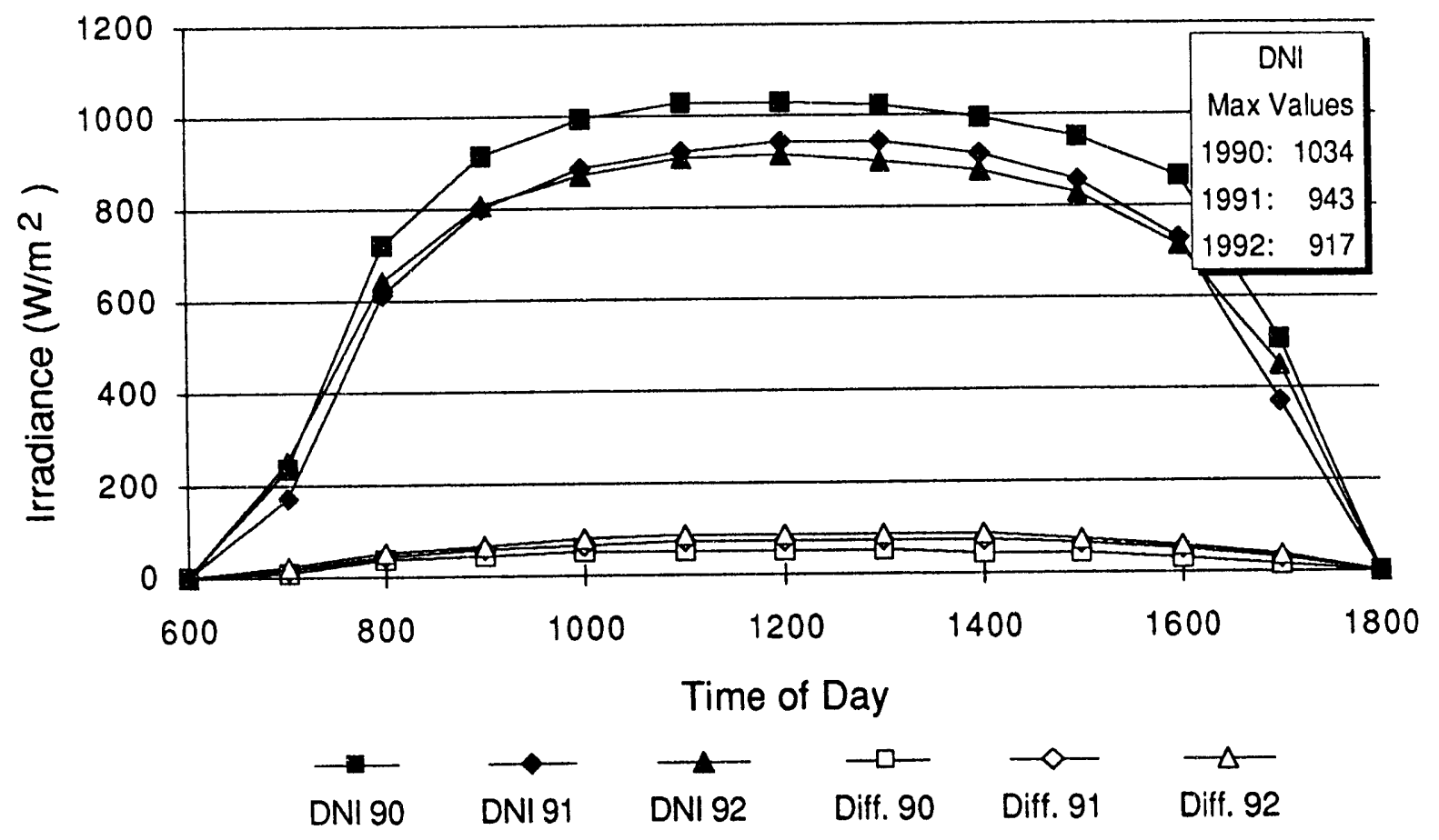

Figure 3-6. Direct Normal and Diffuse Irradiance -- Golden, Colorado 10/21/90, 10/21/91, 10/10/92.

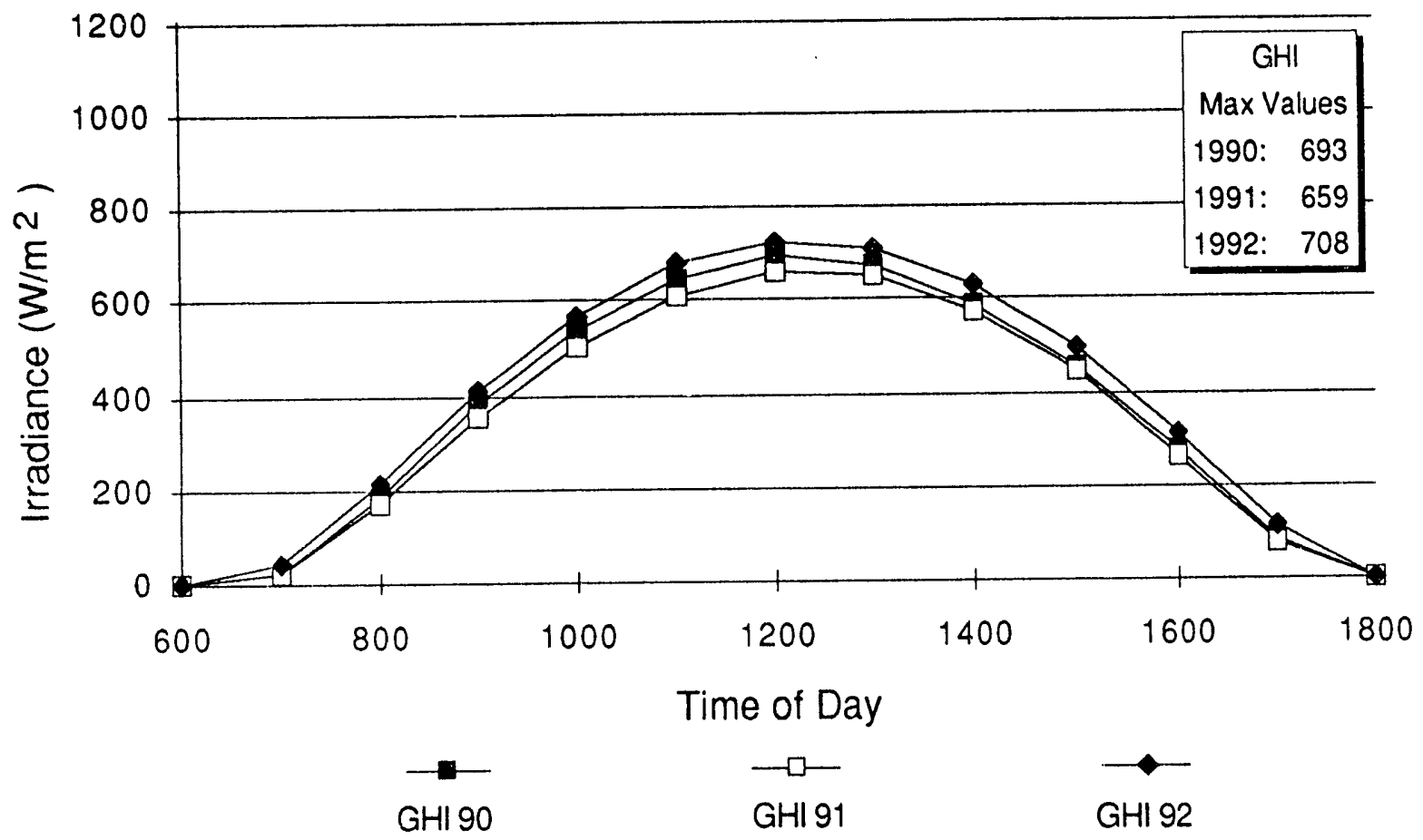

Figure 3-7. Global Horizontal Irradiance -- Golden, Colorado 10/21/90, 10/21/91, 10/10/92. 


\subsection{CARRISA PLAINS. CALIFORNIA}

Pacific Gas and Electric Company (PG\&E) has conducted weather monitoring under its Solar Insolation Monitoring Project (SIMP) at 14 different sites throughout its service territory in northern and central California since 1984. For this report, PG\&E made available data recorded at Carrisa Plains, California. The site is in the California valley in the central region of the state. The longitude and latitude of the location are $W$ $120.05^{\circ}$ and $N$ 35.35 . The elevation is 609 meters (2000 feet). On site is an Eppley Normal Incidence Pyrheliometer (NIP) to measure direct normal irradiance, and an Eppley Precision Spectral Pyranometer (PSP) to measure global horizontal irradiance.

\subsection{Recorded Insolation}

Table 4-1 presents the direct normal insolation recorded in Carrisa Plains for the period of January 1990 through April 1992.

Table 4-1

Direct Normal Insolation for Carrisa Plains, California: 1990 - 1992

$\begin{array}{lccc}\text { Month } & \begin{array}{c}1990 \\ \left(\mathrm{kWh} / \mathrm{m}^{2}\right)\end{array} & \begin{array}{c}1991 \\ \left(\mathrm{kWh} / \mathrm{m}^{2}\right)\end{array} & \begin{array}{c}1992 \\ \left(\mathrm{kWh} / \mathrm{m}^{2}\right)\end{array} \\ \text { January } & 153.9 & 138.6 & 130.9 \\ \text { February } & 148.0 & 153.4 & 92.0 \\ \text { March } & 189.8 & 140.4 & 81.4 \\ \text { April } & 208.5 & 221.8 & 190.5 \\ \text { May } & 271.4 & 276.2 & - \\ \text { June } & 318.2 & 281.2 & - \\ \text { July } & 320.1 & 304.9 & - \\ \text { August } & 287.8 & 268.6 & - \\ \text { September } & 248.4 & 233.0 & - \\ \text { October } & 244.7 & 206.1 & - \\ \text { November } & 192.0 & 168.7 & - \\ \text { December } & 183.3 & 118.3 & -\end{array}$

Table 4-2 presents the global horizontal insolation recorded in Carrisa Plains during the same three-year period. 
Table 4-2

Global Horizontal Insolation for Carrisa Plains, California: $1990-1992$

$\begin{array}{lccc}\text { Month } & \begin{array}{c}1990 \\ \left(\mathrm{kWh} / \mathrm{m}^{2}\right)\end{array} & \begin{array}{c}1991 \\ \left(\mathrm{kWh} / \mathrm{m}^{2}\right)\end{array} & \begin{array}{c}1992 \\ \left(\mathrm{kWh} / \mathrm{m}^{2}\right)\end{array} \\ \text { January } & 95.5 & 91.6 & 97.3 \\ \text { February } & 114.7 & 110.6 & 98.4 \\ \text { March } & 169.1 & 137.8 & 126.5 \\ \text { April } & 198.9 & 206.3 & 206.0 \\ \text { May } & 243.0 & 247.3 & - \\ \text { June } & 261.9 & 248.5 & - \\ \text { July } & 262.8 & 253.9 & - \\ \text { August } & 234.4 & 222.7 & - \\ \text { September } & 187.2 & 185.3 & - \\ \text { October } & 157.4 & 145.8 & - \\ \text { November } & 109.8 & 110.1 & - \\ \text { December } & 95.1 & 84.5 & -\end{array}$

Figure 4-1 shows the Direct Normal Irradiance (DNI) recorded over the three-year period. Two data points are plotted for each day: the half-hourly average value recorded for the period from 11:30 am to $12: 00 \mathrm{pm}$ and the half-hourly average value recorded for the period from 12:00 pm to $12: 30 \mathrm{pm}$.

The effects of the Pinatubo eruption are seen in Figure 4-1. During the period of January 1990 through June 1991, the clear sky DNI often reached levels of $1000 \mathrm{~W} / \mathrm{m}^{2}$. Following the Pinatubo eruption in June 1991, a steady decline in the clear sky DNI values was recorded. Midday DNI levels declined to approximately $900 \mathrm{~W} / \mathrm{m}^{2}$ or less. After the eruption, values in excess of $1000 \mathrm{~W} / \mathrm{m}^{2}$ were no longer observed.

Figure 4-2 shows the Global Horizontal Irradiance (GHil) recorded for the three-year period. As with other sites, effects of the volcano on the global irradiance are less discernible than effects on the direct normal component. 


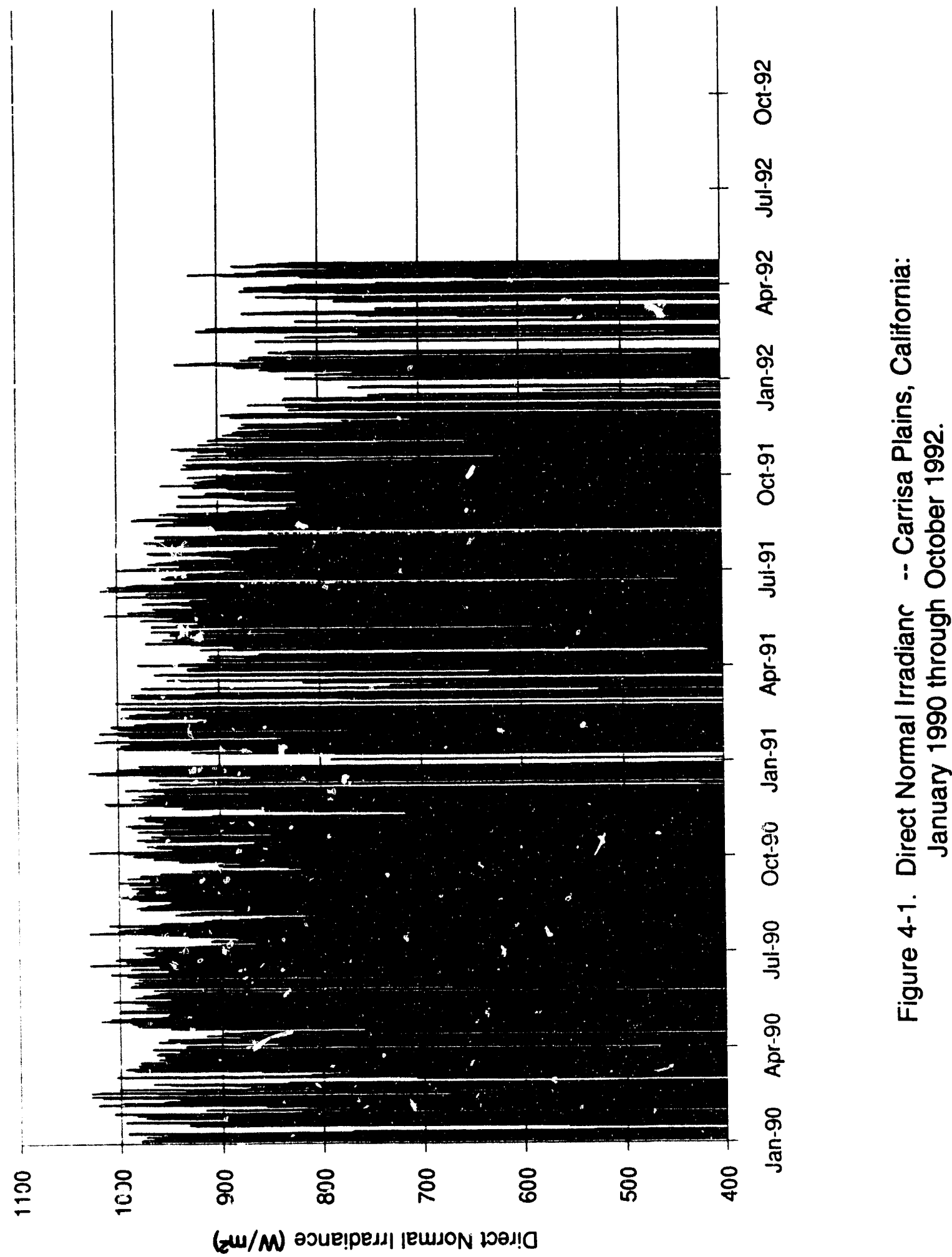




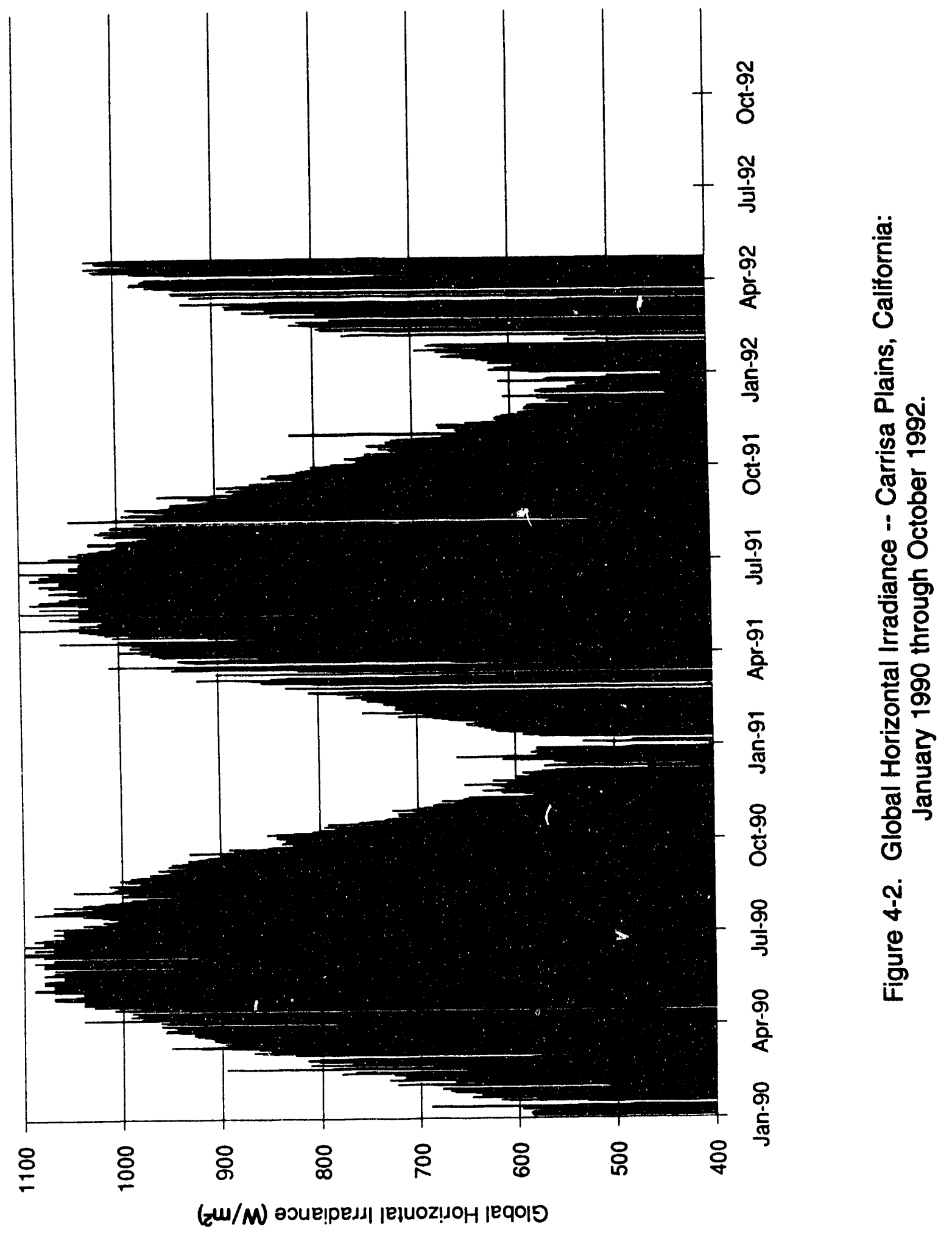




\subsection{Effects on Direct Normal Irradiance}

Figure 4-3 presents a qualitative illustration of the effects of the Pinatubo eruption on DNI levels recorded in Carrisa Plains, CA. The figure shows daily quotients of 1991 vs. 1990 and 1992, vs. 1990 'clear sky' DNI values. Data for 1992 are available only through the end of April. As outlined in the previous section, the method used to screen for clear sky conditions was to extract, for each day of the year, the single maximum DNI value observed during a 15-day period. That is, for day $n$, the value used was the maximum DNI observed in the period of day $n-7$ to day $n+7$. Quotients were generated by dividing the extracted value for each day of 1991 and 1992 by its corresponding 1990 value. In this way, the 1991 and 1992 data were indexed against pre-eruption (1990) conditions.

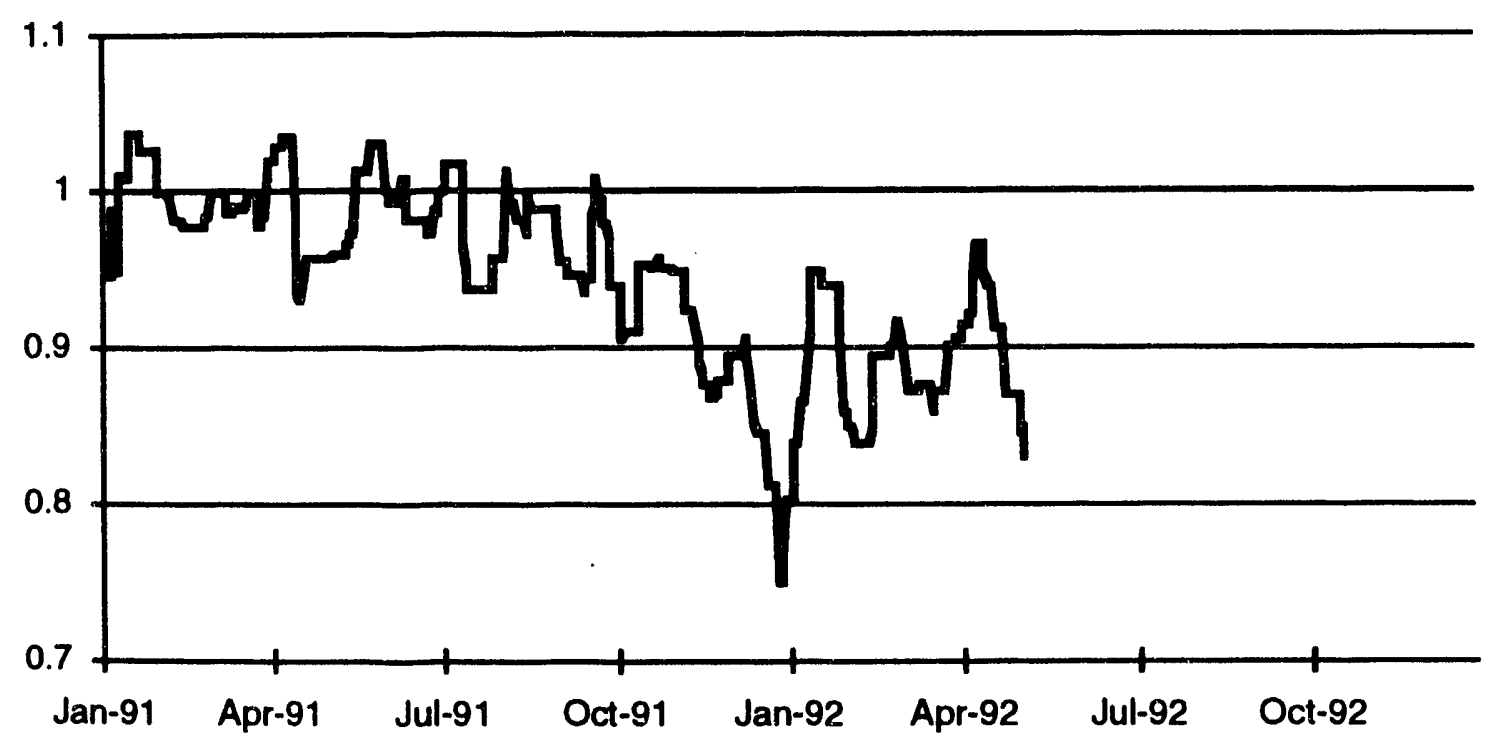

Figure 4-3. Clear Sky DNI Quotients -- Carrisa Plains, CA 1991/1990 and 1992/1990.

For the months prior to the eruption, 1991 clear sky DNI values were similar to what they had been in 1990. Ratios remained approximately equal to 1.0. Following the eruption, clear sky DNI values declined. During December 1991 and January 1992, DNI values fell to approximately $80 \%$ of their 1990 levels. During spring 1992, the effects of the eruption moderated, as observed at other sites. Data are not available after April 1992. 


\subsection{Iypical Cloudless Days}

The data were examined to select days that had been cloudless or near cloudless in each of the three years of the reporting period. Three sets of these days are presented here.

Figure 4-4 shows DNI and diffuse data recorded during individual days in January of three consecutive years: January 21, 1990; January 23, 1991; and January 23, 1992. The 1990 and 1991 data were recorded prior to the eruption. The diffuse data for all three years have been calculated. Figure 4-5 shows the GHI data recorded during these three days.

As shown in Figure 4-4, the DNI levels recorded during 1990 and the pre-eruption period of 1991 were roughly comparable. The 1992 levels have been attenuated by the eruption. Expressed on a percentage basis, the DNI was down $5 \%\left(49 \mathrm{~W} / \mathrm{m}^{2}\right)$ in 1992 compared with 1990, and down $10 \%\left(100 \mathrm{~W} / \mathrm{m}^{2}\right)$ when compared with 1991.

Conversely, the midday 1992 diffuse data show an increase of approximately $50 \mathrm{~W} / \mathrm{m}^{2}$ compared with 1990, and $70 \mathrm{~W} / \mathrm{m}^{2}$ compared with 1991.

Figure 4-6 shows the DNI and diffuse data recorded during December 8, 1990, and December 4, 1991. Figure 4-7 shows the GHI data recorded during these two days. Data for this day in 1992 are not available. In this case, the 1991 data were recorded six months after the eruption. The DNI values recorded at 12:00 were 993 and 897 $\mathrm{W} / \mathrm{m}^{2}$ in 1990 and 1991, respectively. The 1991 diffuse irradiance increased by 50 $\mathrm{W} / \mathrm{m}^{2}$ compared with 1990 . Interestingly, despite these changes, the net result left the $\mathrm{GHI}$ values for the two years virtually identical. 


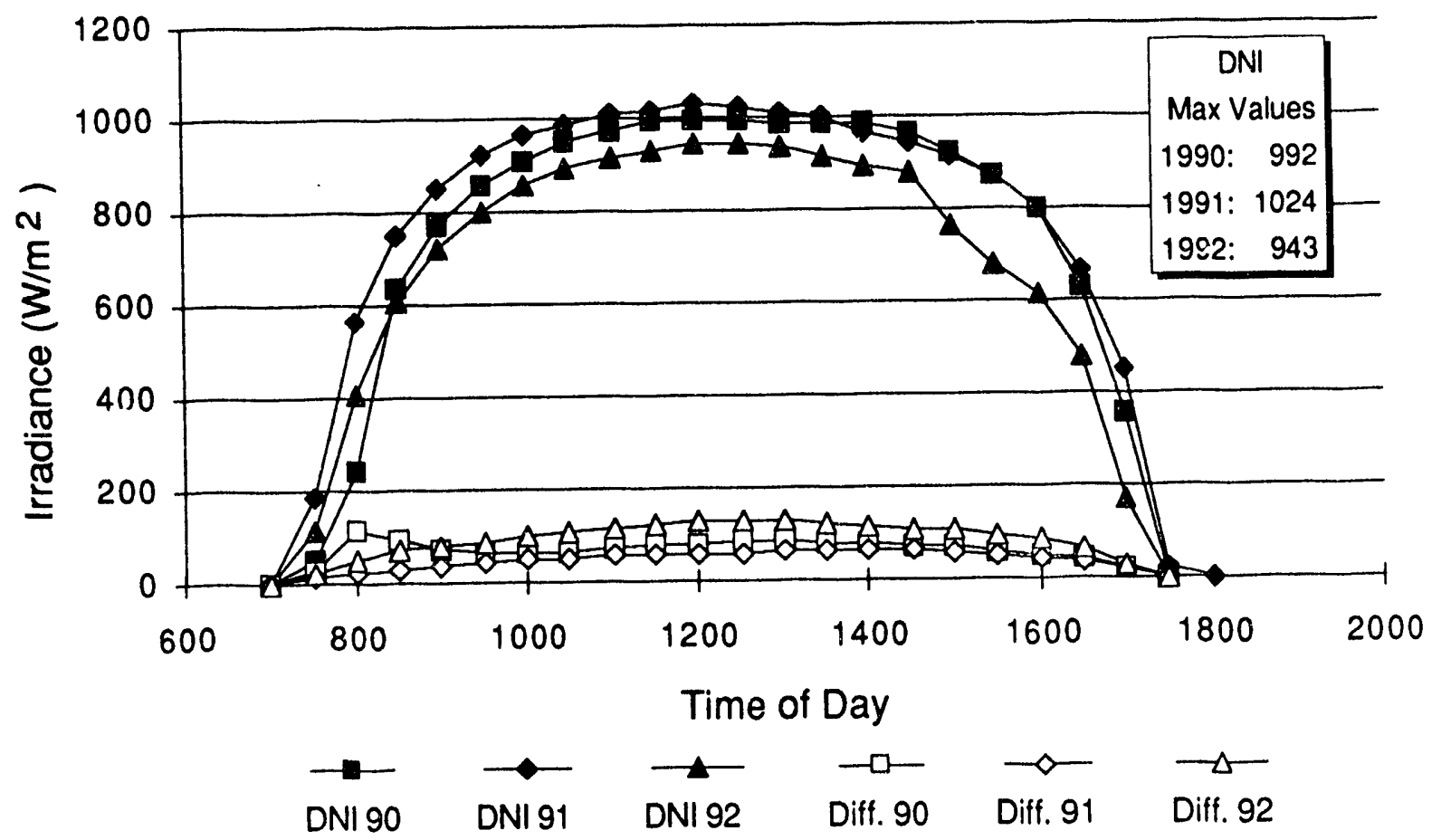

Figure 4-4. Direct Normal and Diffuse Irradiance -- Carrisa Plains, California $1 / 21 / 90,1 / 23 / 91,1 / 23 / 92$.

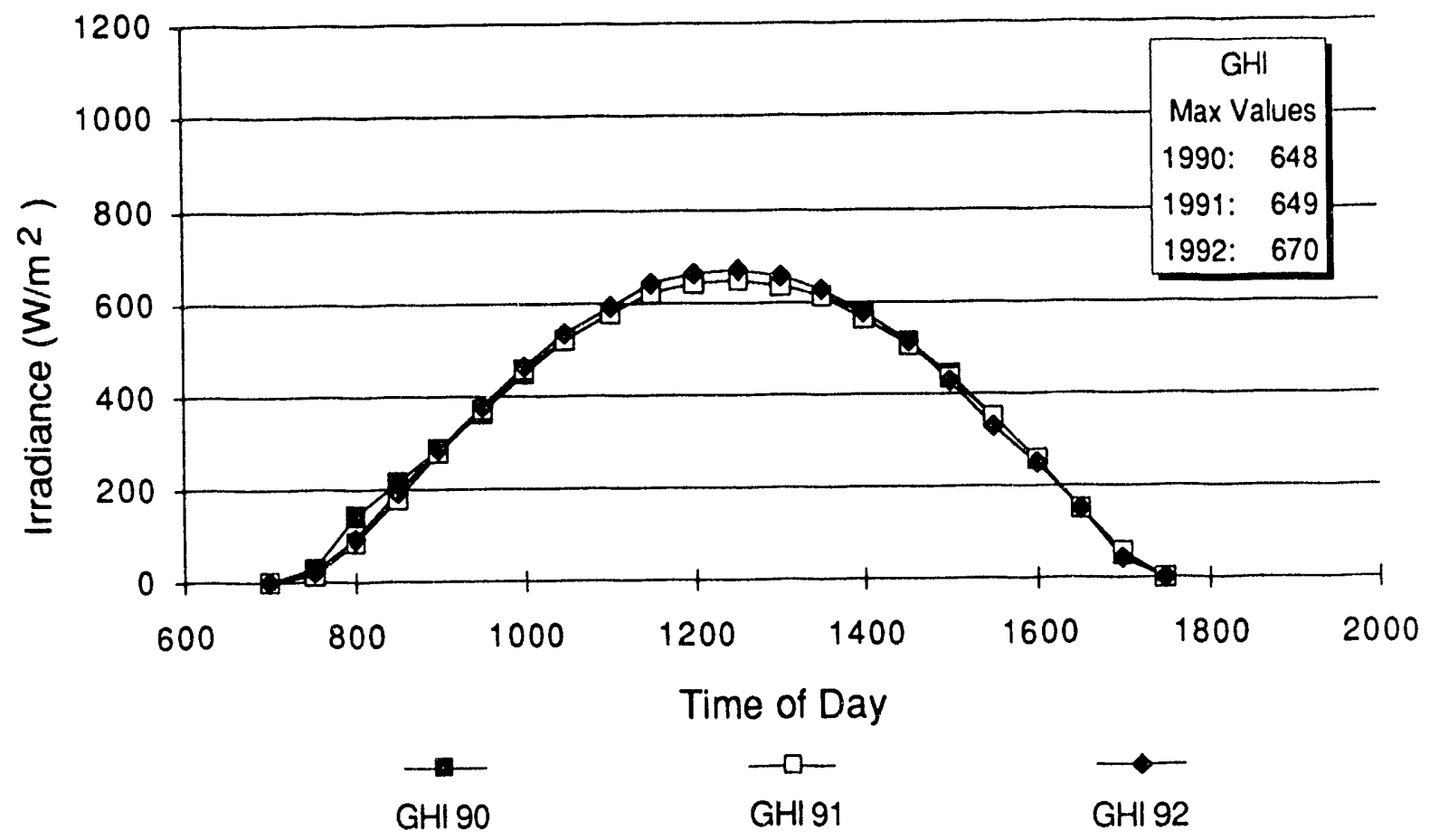

Figure 4-5. Global Horizontal Irradiance -- Carrisa Plains, California $1 / 21 / 90,1 / 23 / 91,1 / 23 / 92$. 


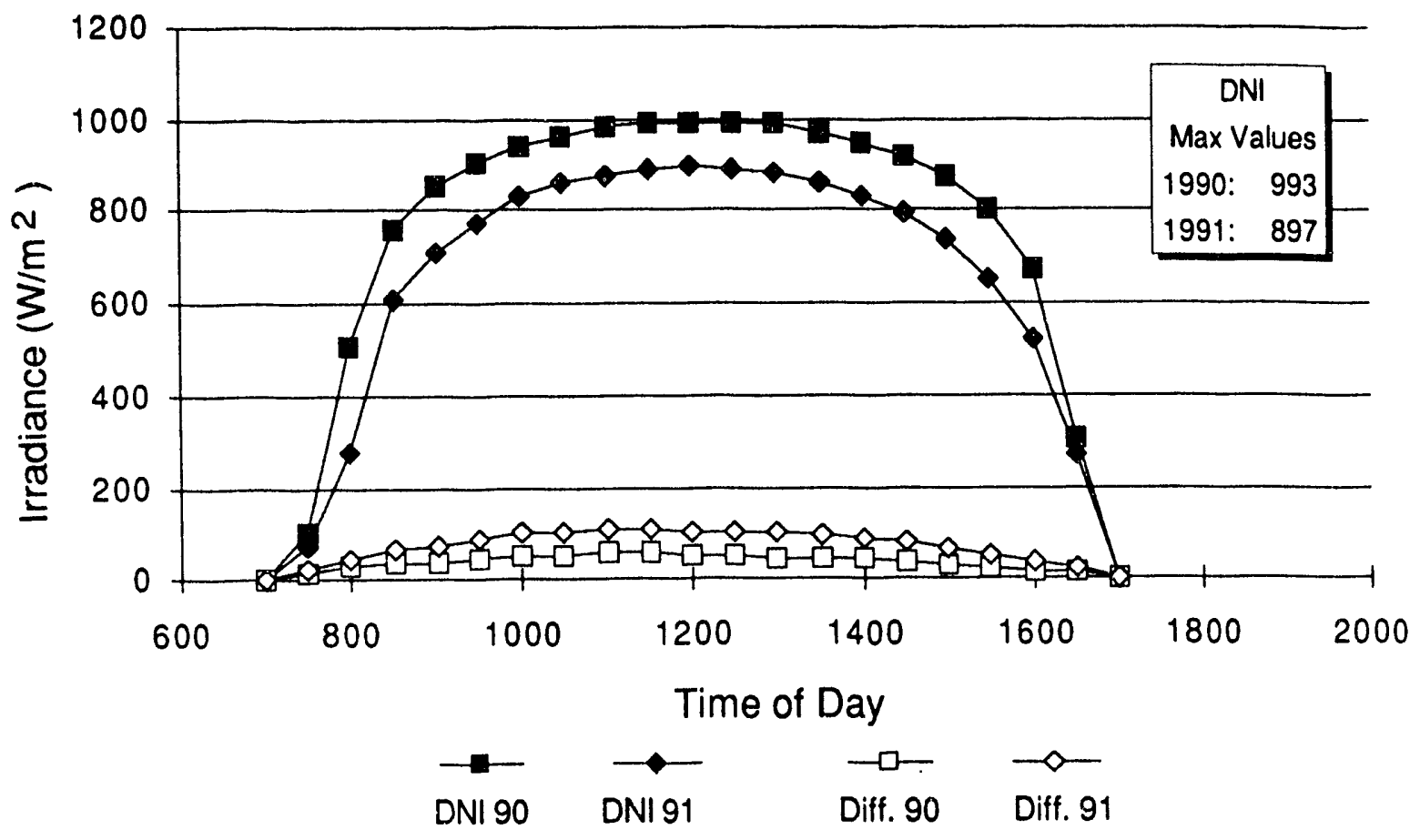

Figure 4-6. Direct Normal and Diffuse Irradiance -- Carrisa Plains, California $12 / 8 / 90,12 / 4 / 91$.

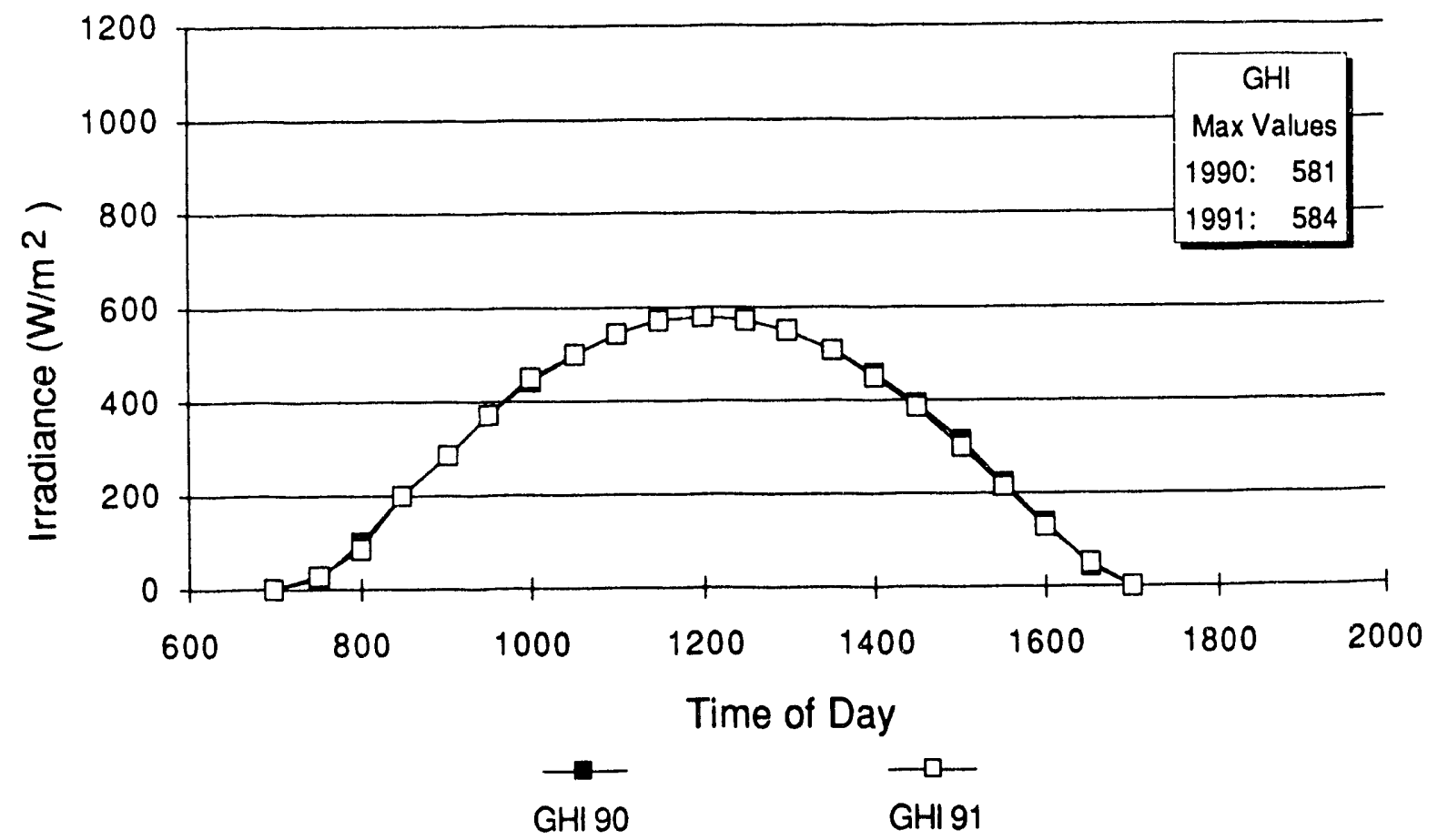

Figure 4-7. Global Horizontal Irradiance -- Carrisa Plains, California $12 / 8 / 90,12 / 4 / 91$. 


\subsection{ALBUQUERQUE, NEW MEXICO}

Solar resource data have been recorded at the Solar Insolation monitor station at Sandia National Laboratories (SNL) in Albuquerque, New Mexico, since February 1991. The site is west of the Rio Grande, in the foothills of the Sandia Mountains, in the central region of the state. The longitude and latitude of the location are $W 106.62^{\circ}$ and $\mathrm{N} 35.05^{\circ}$. The elevation is 1619 meters (5310 feet). On site is an Eppley Normal Incidence Pyrheliometer (NIP) to measure direct normal irradiance, an Eppley Precision Spectral Pyranometer (PSP) to measure global horizontal irradiance, and an Eppley shadow band and PSP to measure horizontal diffuse irradiance.

\subsection{Recorded Insolation}

Table 5-1 presents the direct normal insolation recorded in Albuquerque for the period of February 1991 through December 1992.

\section{Table 5-1}

Direct Normal Insolation for Albuquerque, New Mexico: 1991 - 1992

$\begin{array}{lcc}\text { Month } & \begin{array}{c}1991 \\ \left(\mathrm{kWh} / \mathrm{m}^{2}\right)\end{array} & \begin{array}{c}1992 \\ \left(\mathrm{kWh} / \mathrm{m}^{2}\right)\end{array} \\ \text { January } & - & 130.5 \\ \text { February } & 147.5 & 109.5 \\ \text { March } & 169.1 & 138.9 \\ \text { April } & 266.7 & 205.2 \\ \text { May } & 289.2 & 150.3 \\ \text { June } & 246.7 & 234.5 \\ \text { July } & 192.6 & 207.1 \\ \text { August } & 209.6 & 218.4 \\ \text { September } & 180.2 & 229.2 \\ \text { October } & 205.7 & 162.4 \\ \text { November } & 156.3 & 136.0 \\ \text { December } & 110.9 & 81.2\end{array}$

Table 5-2 presents the global horizontal insolation recorded in Albuquerque during the same period. 
Table 5-2

Global Horizontal Insolation for Albuquerque, New Mexico: 1991 - 1992

$\begin{array}{lcc}\text { Month } & 1991 & 1992 \\ \left(\mathrm{kWh} / \mathrm{m}^{2}\right) & \left(\mathrm{kWh} / \mathrm{m}^{2}\right) \\ \text { January } & - & 90.6 \\ \text { February } & 110.3 & 106.3 \\ \text { March } & 151.4 & 146.0 \\ \text { April } & 213.3 & 200.9 \\ \text { May } & 246.7 & 196.9 \\ \text { June } & 226.6 & 224.4 \\ \text { July } & 211.5 & 214.2 \\ \text { August } & 201.4 & 206.9 \\ \text { September } & 164.9 & 177.9 \\ \text { October } & 143.7 & 129.2 \\ \text { November } & 97.3 & 92.9 \\ \text { December } & 78.2 & 72.1\end{array}$

Figure 5-1 shows the Direct Normal Irradiance (DNI) recorded over the two-year period. Two data points are plotted for each day: the half-hourly average value recorded for the period from 11:30 am to $12: 00 \mathrm{pm}$, and the half-hourly average value recorded for the period from $12: 00 \mathrm{pm}$ to $12: 30 \mathrm{pm}$.

As with the data recorded in Las Cruces, the DNI data recorded in Albuquerque show the effects of the Pinatubo eruption. DNI levels recorded during the first half of 1992 were approximately $10 \%$ less than those recorded during the first half of 1991 . In addition, at no time following the eruption did DNI values reach $1000 \mathrm{~W} / \mathrm{m}^{2}$.

Figure 5-2 shows the Global Horizontal Irradiance (GHI) recorded for the three-year period. Again, the two half-hourly records that bracket solar noon are plotted for each day. In general, the 1992 summer values are slightly lower than those recorded in 1991. 


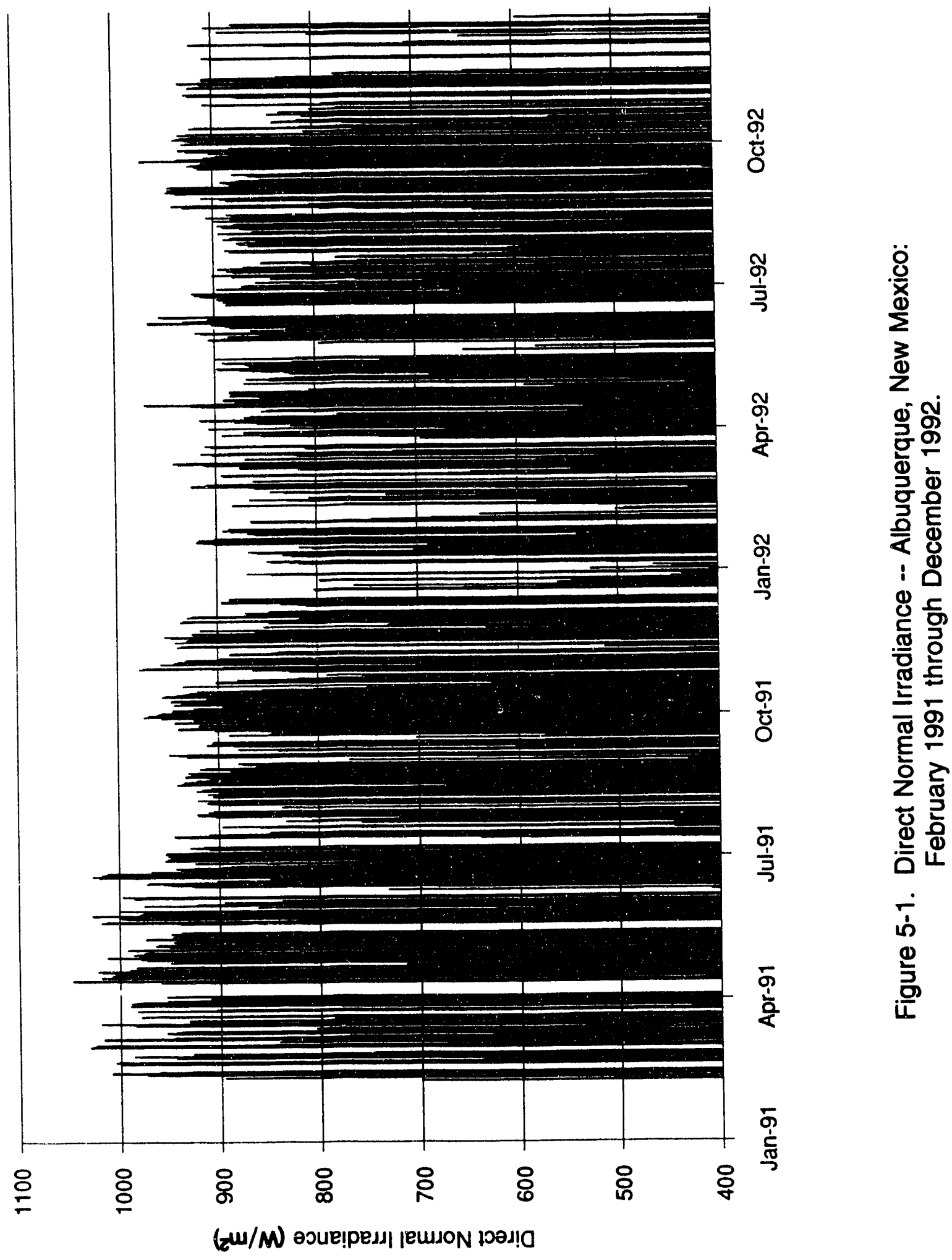




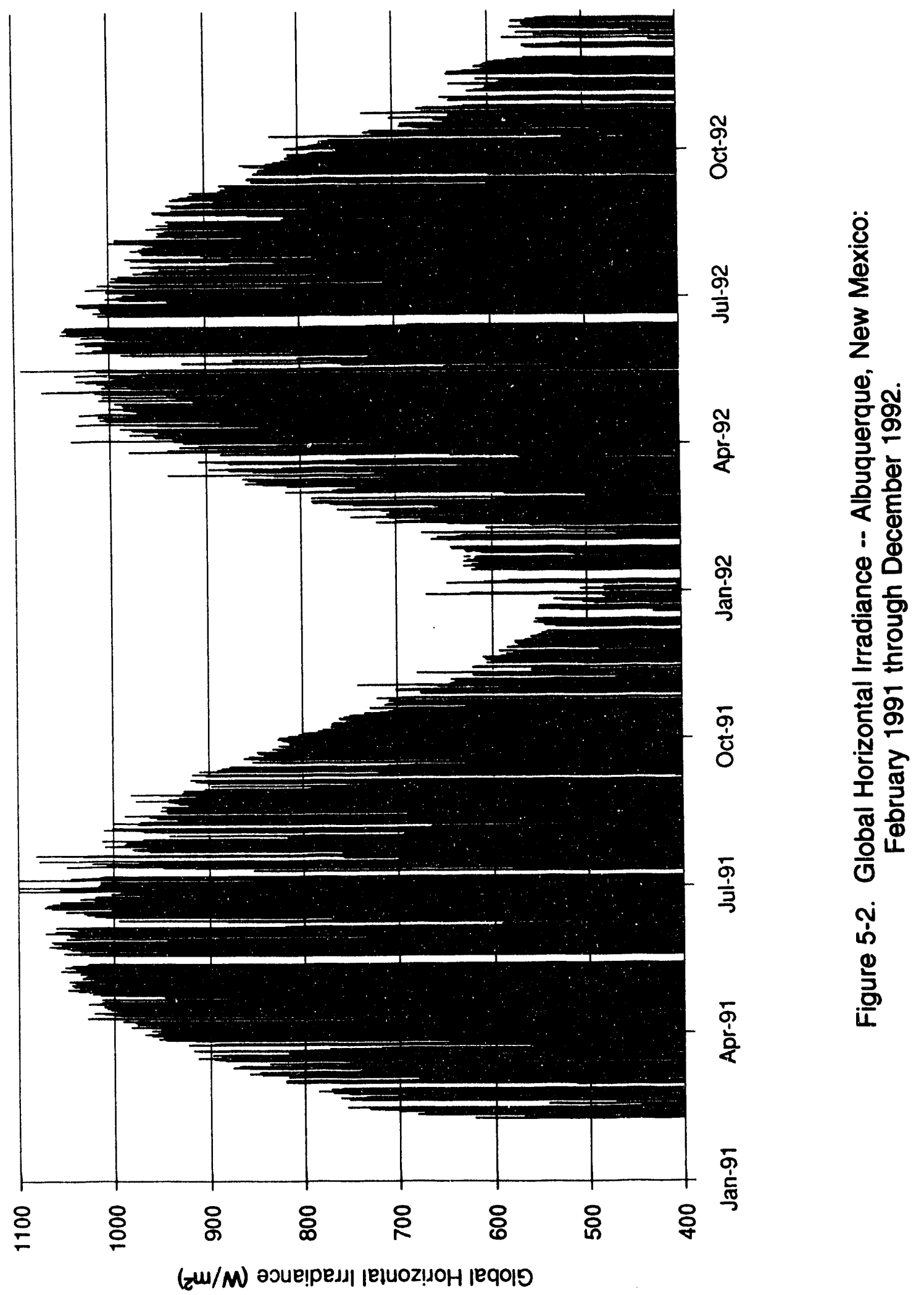




\subsection{Effects on Direct Normal Irradiance}

Figure 5-3 presents a qualitative illustration of the effects of the Pinatubo eruption on DNI levels recorded in Albuquerque, New Mexico. The only pre-eruption data available were for the period of February 1991 through July 1991. Thus, 'clear sky' DNI ratios were generated with data collected from February 1992 through July 1992 (posteruption period) compared with data from February 1991 through July 1991 (preeruption period). As outlined in the previous section, the method used to screen for clear sky conditions extracted, for each day of the year, the single maximum DNI value observed during a 15-day period. That is, for day $n$, the value used was the maximum DNI observed in the period from day $n-7$ to day $n+7$. Quotients were generated by dividing the extracted value for each day of the post-eruption period of 1992 by its corresponding pre-eruption 1991 value. In this way, the 1992 data were indexed against pre-eruption (1991) conditions.

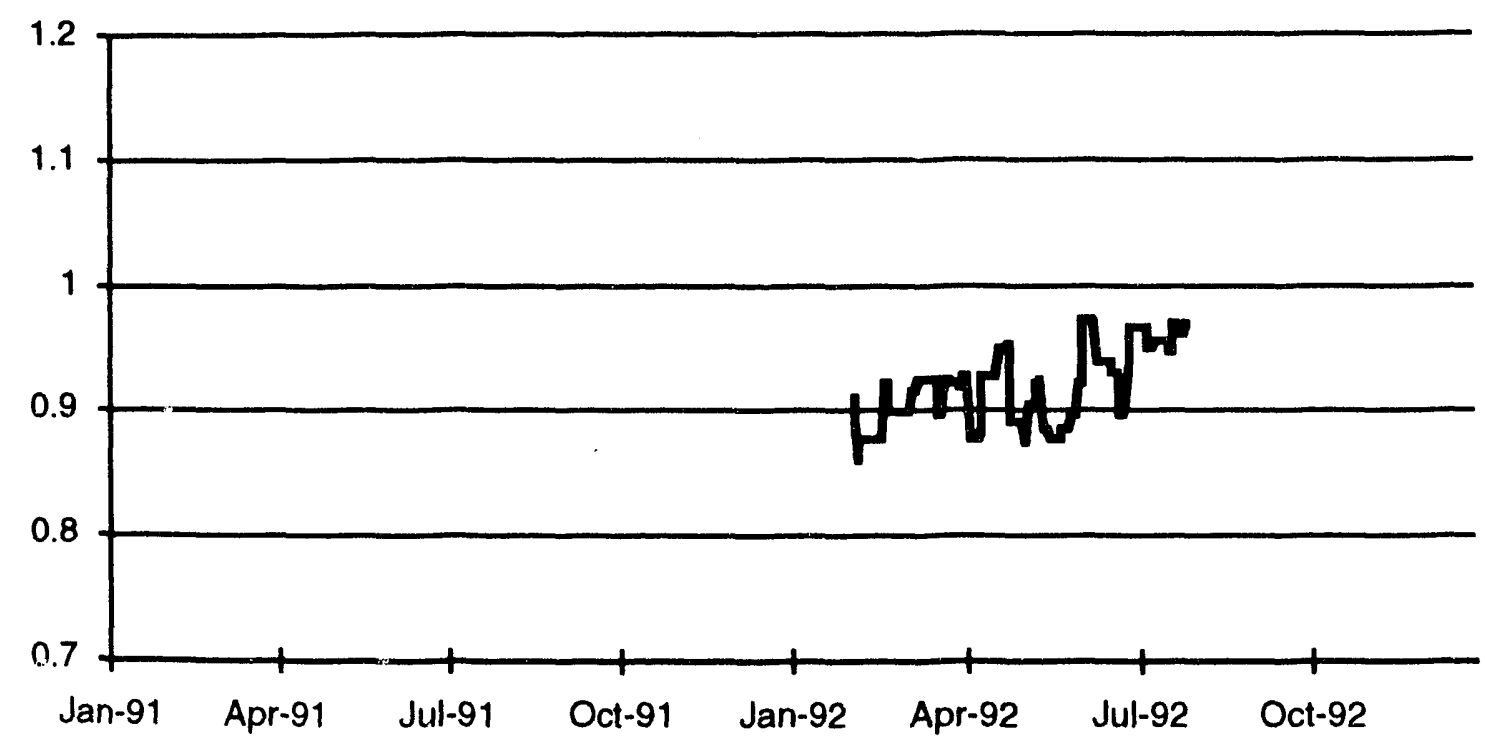

Figure 5-3. Clear Sky DNI Quotients -- Albuquerque, NM 1992/1991.

As described earlier, the effect of the eruption was a reduction of the DNI. In this case, the values recorded during the first quarter of 1992 were approximately $12 \%$ below those recorded during the same period in 1991. By summer 1992, the attenuation of the DNI was less pronounced and the ratio of post- to pre-eruption values began to rise. 


\subsection{Iypical Cloudless Days}

The data were examined to select days that had been cloudless or near cloudless in each of the two years. Two sets of these days are presented here.

Figure 5-4 shows DNI and diffuse irradiance data recorded on individual days in two consecutive years: March 8, 1991, and March 6, 1992. Figure 5-5 shows the GHI data recorded during these two days.

As shown in Figure 5-4, the 1992 DNI data, recorded nine months after the eruption, show attenuation when compared with the pre-eruption data recorded in early 1991. The DNI values recorded at 12:30 were 1017 and $896 \mathrm{~W} / \mathrm{m}^{2}$ in 1991 and 1992 , respectively. Expressed on a percentage basis, the DNI was down $12 \%$ in 1992 compared with 1991. The midday 1992 diffuse data show an increase of approximately $45 \mathrm{~W} / \mathrm{m}^{2}$ compared with 1991.

Figure 5-6 shows the DNI and diffuse data recorded on June 16, 1991, and June 14, 1992. Figure 5-7 shows the GHI data recorded during these two days. As observed elsewhere, the effects of the eruption diminished during the summer months. The DNI values recorded at 12:30 were 929 and $932 \mathrm{~W} / \mathrm{m}^{2}$ in 1991 and 1992, respectively. 


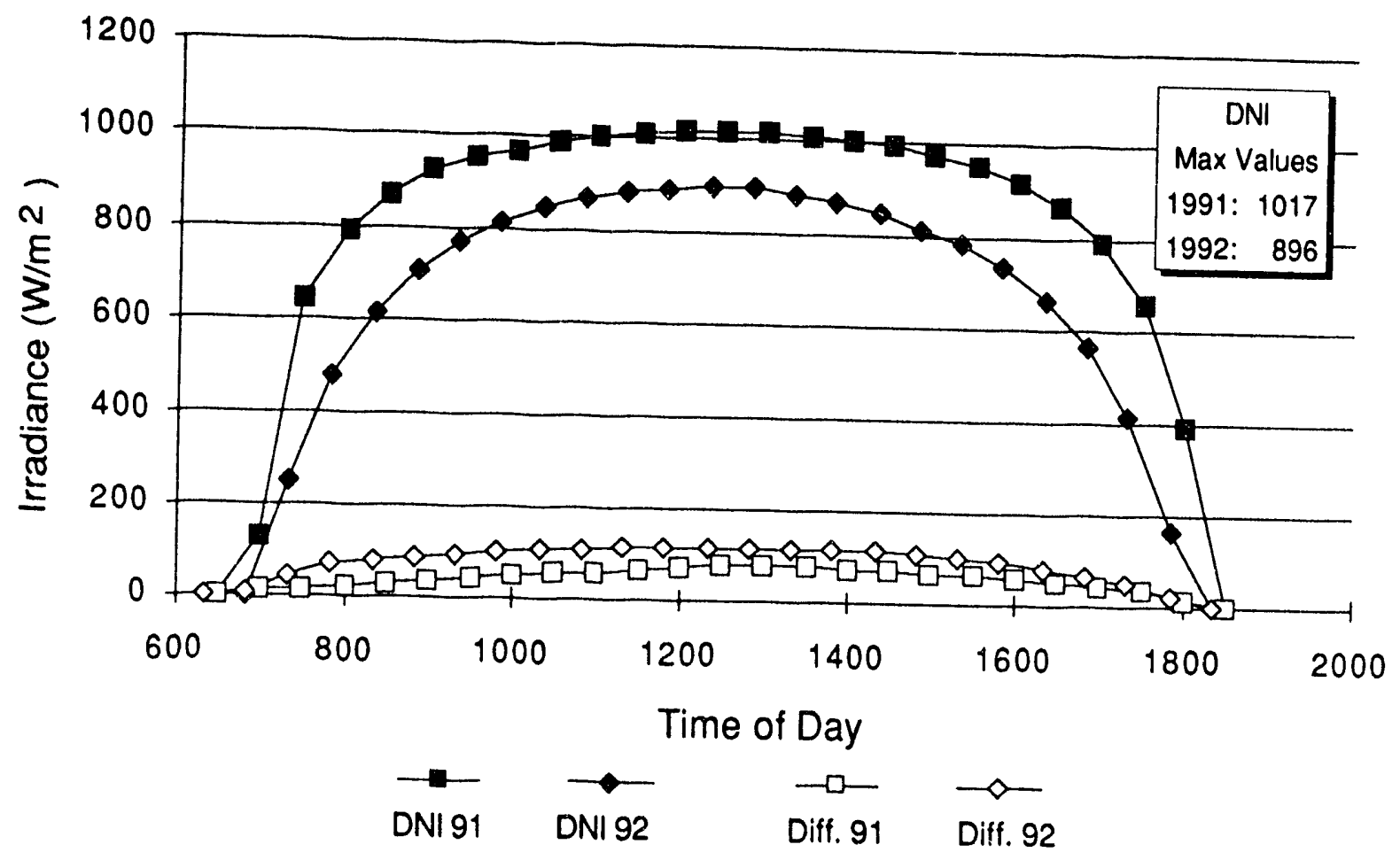

Figure 5-4. Direct Normal and Diffuse Irradiance -- Albuquerque, New Mexico $3 / 8 / 91,3 / 6 / 92$.

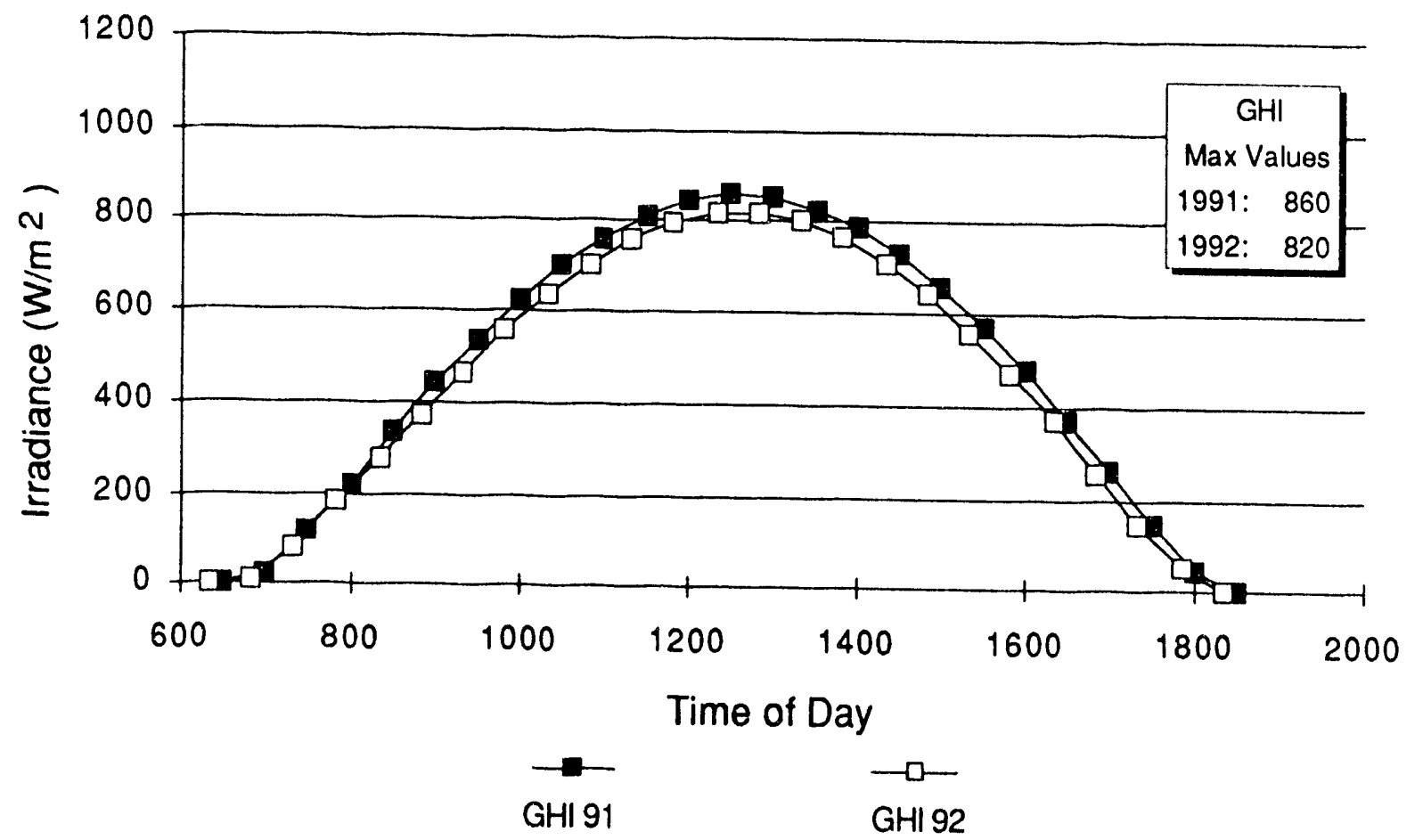

Figure 5-5. Global Horizontal Irradiance -- Albuquerque, New Mexico $3 / 8 / 91,3 / 6 / 92$. 


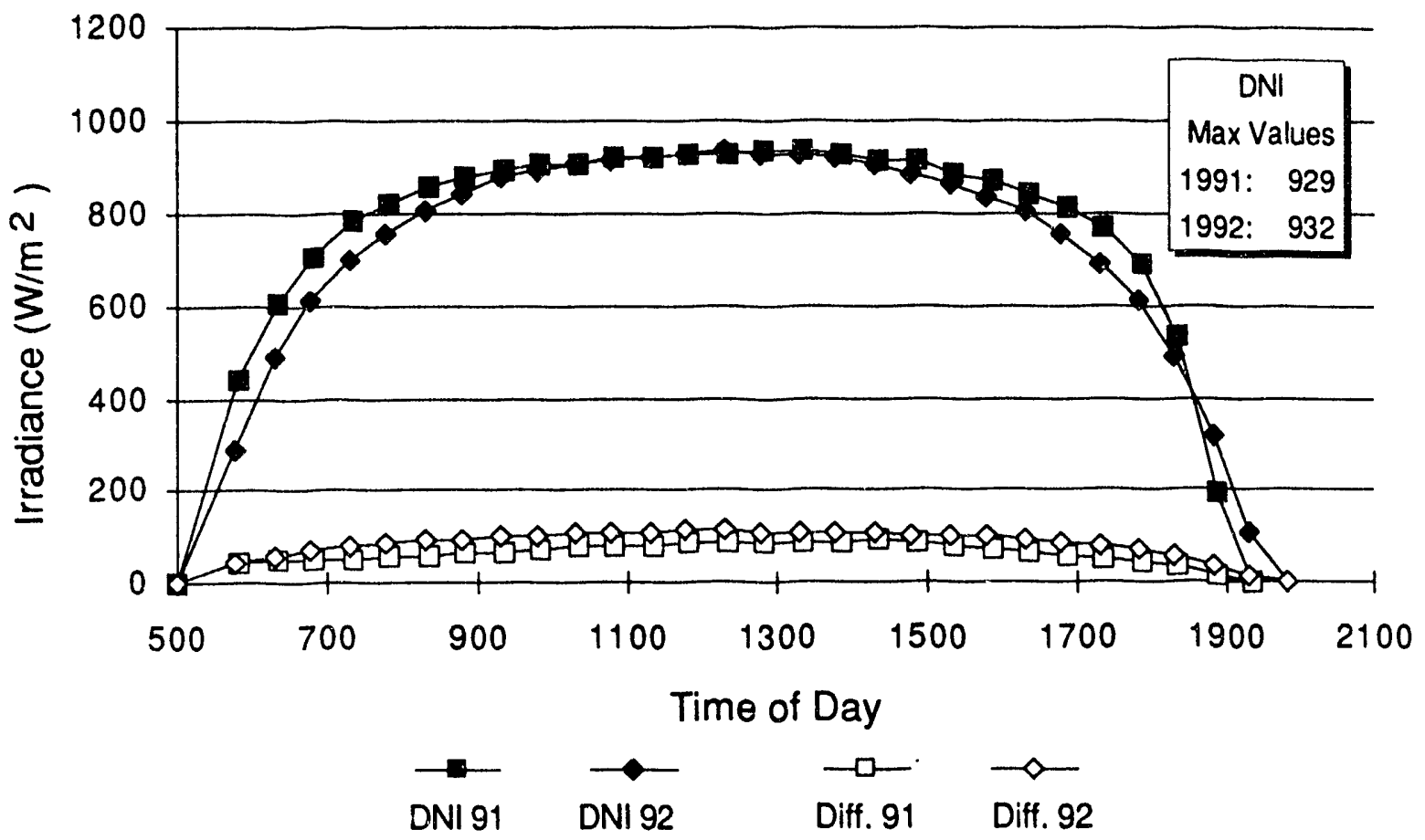

Figure 5-6. Direct Normal and Diffuse Irradiance -- Albuquerque, New Mexico $6 / 16 / 91,6 / 14 / 92$.

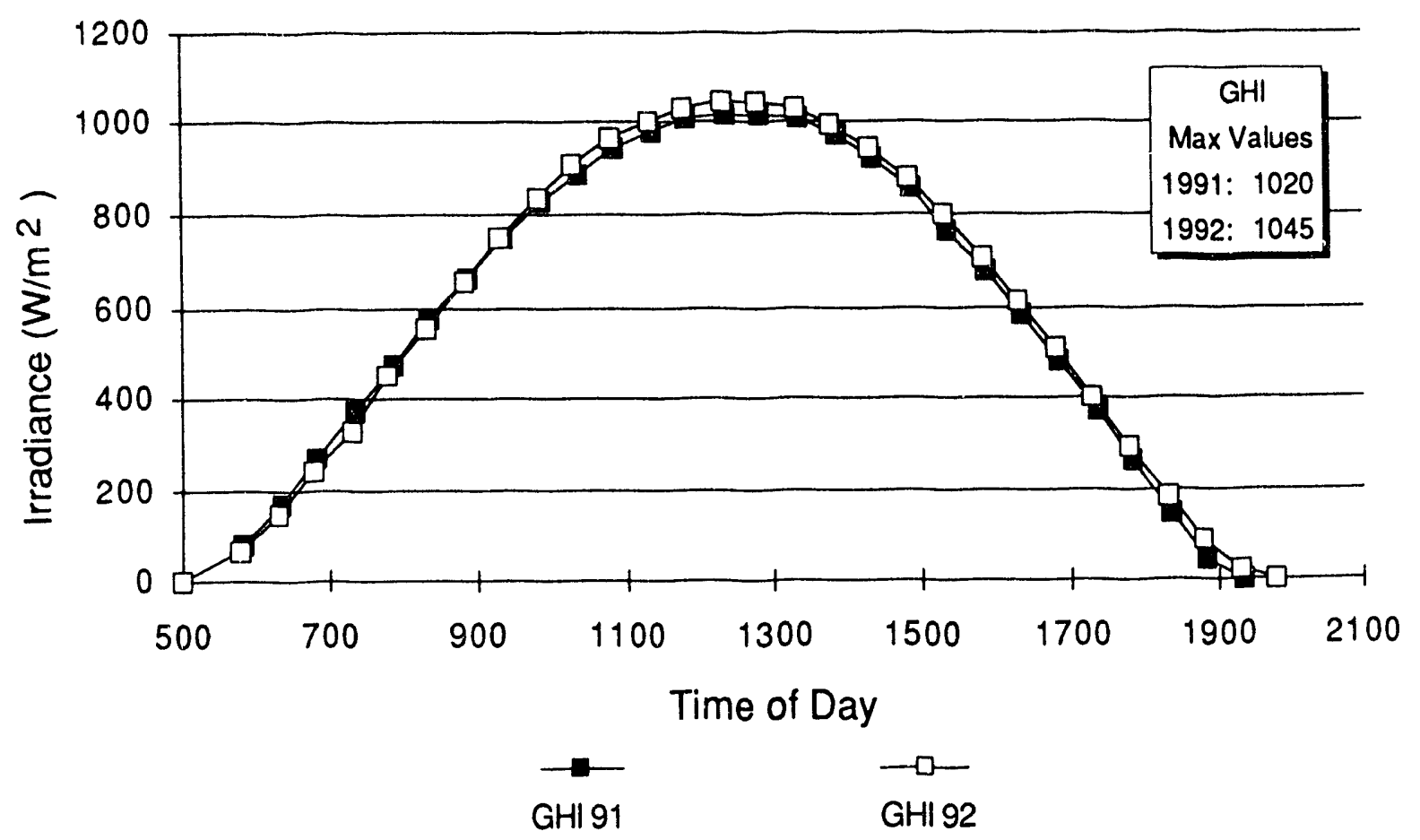

Figure 5-7. Global Horizontal Irradiance -- Albuquerque, New Mexico $6 / 16 / 91,6 / 14 / 92$. 


\subsection{DATA QUALITY ASSURANCE}

Several steps of quality assurance (QA) checking were applied to all data used in this report. Data fields that failed QA were flagged and the flagged fields were manually inspected before any action was taken. Remediation of a flagged field was possible for sites that monitor global horizontal, direct normal, and horizontal diffuse irradiance when only a single field was erroneous per given record. When more than one field per record was flagged, or when less thin three solar instruments were in use, the flagged values were examined and discarded.

Throughout all QA processing, the value of $1367 \mathrm{~W} / \mathrm{m}^{2}$ was used for the solar constant. Solar position was calculated according to the method outlined by lqbal (5).

For each site, the first step of QA was gross range checking of the data. At the low end, all negative values were flagged. To evaluate the upper limit, a clear sky value for transmittance of beam radiation was calculated according to Hottel (6). This model requires the derivation of site-specific coefficients. These were refined via inspection against actual data from each site and ultimately selected to pass all but the most recognizably egregious data. The upper limit of acceptability for DNI was 1.2 times the product of the solar constant times the calculated transmittance coefficient. Horizr:...al irradiance was compared against this 'spper limit timer the cosine of the sun's zenith angle. For diffuse irradiance, any value was flagged that exseeded 0.9 times the global horizontal irradiance.

At three of the four sites, direct normal, horizontal diffuse, and global horizontal irradiance are monitored. Testing was performed to determine whether the global horizontal irradiance was within $10 \%$ of the sum of the diffuse irradiance plus the product of the direct normal irradiance times the cosine of the solar zenith angle. When data from Las Cruces consistently failed this test, it was discovered that the datalogger clock had drifted. Correction of the time stamp associated with the data records was undertaken. This enabled all of the data to pass QA.

Though time consuming, the requ'ement that all questic rable data be manually inspected has proven to be a prudent practice in the preparation of reports of this kind. 


\subsection{CONCLUSIONS}

Analysis of recorded data from four sites in the western United States has revealed some of the effects of the eruption of Mount Pinatubo on solar insolation levels. Conclusions based upon these analyses are:

- Direct normal irradiance has been reduced from historical levels. The attenuation of DNI has followed a cyclical pattern: greatest attenuation during the winter months, less during the summer months. During Jaruary 1992 , clear sky DNI values were only $80 \%$ to $85 \%$ of the values recorded in 1990. During the summer of 1992, these values were essentially unchanged from their 1990 levels. By December 1992, clear sky DNI was again attenuated, reaching only $85 \%$ to $95 \%$ of 1990 levels.

- Greater scattering due to volcanic aerosols increased the level of horizontal diffuse irradiance following the eruption. Increases over historical levels of $100 \%\left(50-60 \mathrm{~W} / \mathrm{m}^{2}\right)$ were recorded during the first winter months following the eruption.

- The eruption's net effect on global horizontal irradiance has been less pronounced than on the direct and diffuse irradiance components. 


\section{SUMMARY}

The objectives of this report were to identify and to quantify the effects of the Mount Pinatubo eruption of June 1991 on solar insolation levels. Solar insolation data from four sites in the western United States were obtained for analysis. The four sites studied were:

- The Southwest Region Experiment Station in Las Cruces, New Mexico;

- The Solar Radiation Research Laboratory at the National Renewable Energy Laboratory in Golden, Colorado;

- The Solar Insolation Monitor Program station operated by the Pacific Gas and Electric Company in Carrisa Plains, California;

- The Solar Insolation monitor station at Sandia National Laboratories in Albuquerque, New Mexico.

In general, the findings for all four sites are consistent. At each location, Direct Normal Irradiance (DNI) was reduced following the eruption. The greatest attenuation of the DNI was observed during the winter of 1991/92. At this time, clear sky DNI levels reached only $80 \%$ to $90 \%$ of the values recorded a year earlier.

At all sites, attenuation due to the eruption abated during the spring and summer of 1992. DNI levels recorded on clear days in the summer of 1992 were similar to those recorded prior to the eruption.

During the latter half of 1992, the second winter following the eruption, attenuated DNI levels were again observed. Clear sky DNI levels for the fall and winter of 1992 were approximately $85 \%$ to $95 \%$ of the values recorded in 1990 .

Diffuse horizontal irradiance levels increased following the eruption. Midday clear sky levels increased $50-60 \mathrm{~W} / \mathrm{m}^{2}$ during the winter of 1991/92. The net effect, therefore, on the Global Horizontal Irradiance (GHI) was far less than on the DNI.

To illustrate Pinatubo's effects, plots showing comparisons of 1991 vs. 1990 and 1992 vs. 1990 'clear sky' DNI values were made. The method used to screen for clear sky conditions extracted, for each day of the year, the single maximum DNI value observed during a 15-day period. That is, for day $n$, the value used was the maximum DNI 
observed in the period from day $n-7$ to day $n+7$. Quotients were generated by dividing the extracted value for each day of 1991 and 1992 by its corresponding 1990 value. In this way, the 1991 and 1992 data were indexed against pre-eruption (1990) conditions. Figure S-1 shows the normalized clear sky DNI ratios obtained for Las Cruces, New Mexico. Figure S-2 shows the same ratios generated for Golden, Colorado.

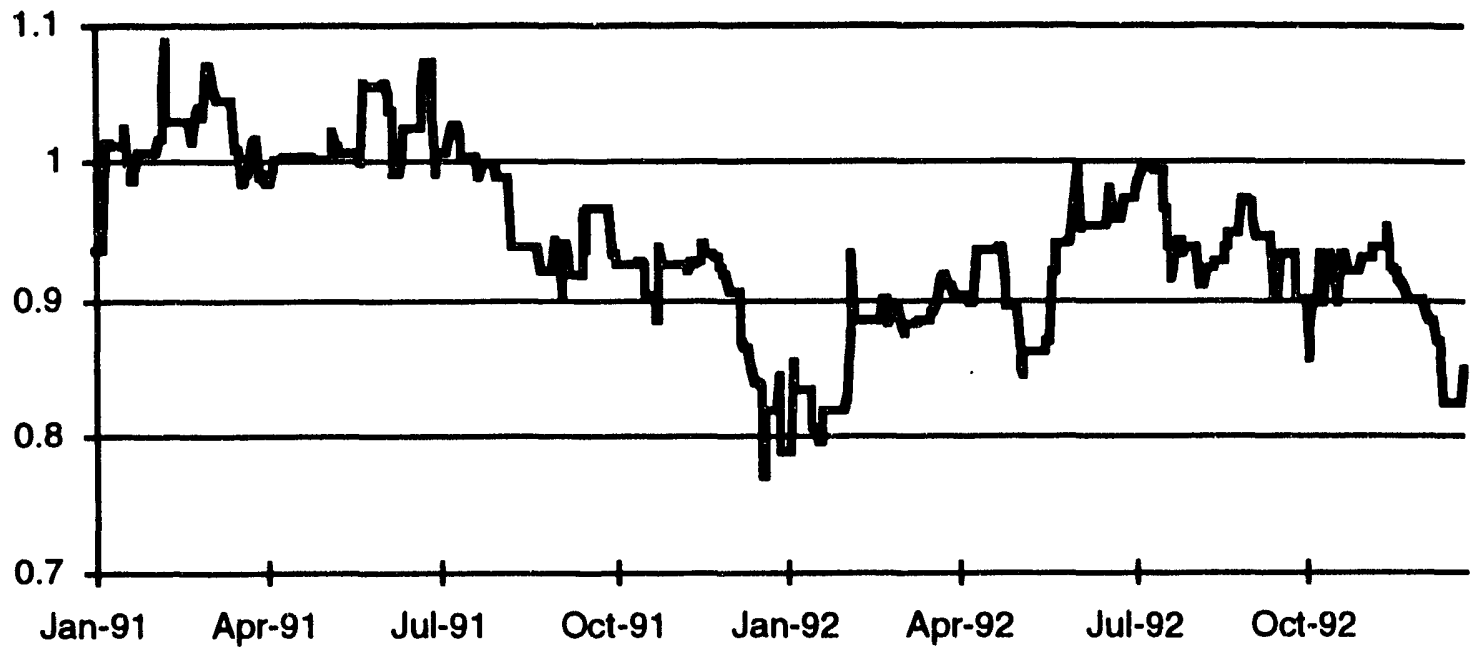

Figure S-1. Clear Sky DNI Quotients .-. Las Cruces, NM.

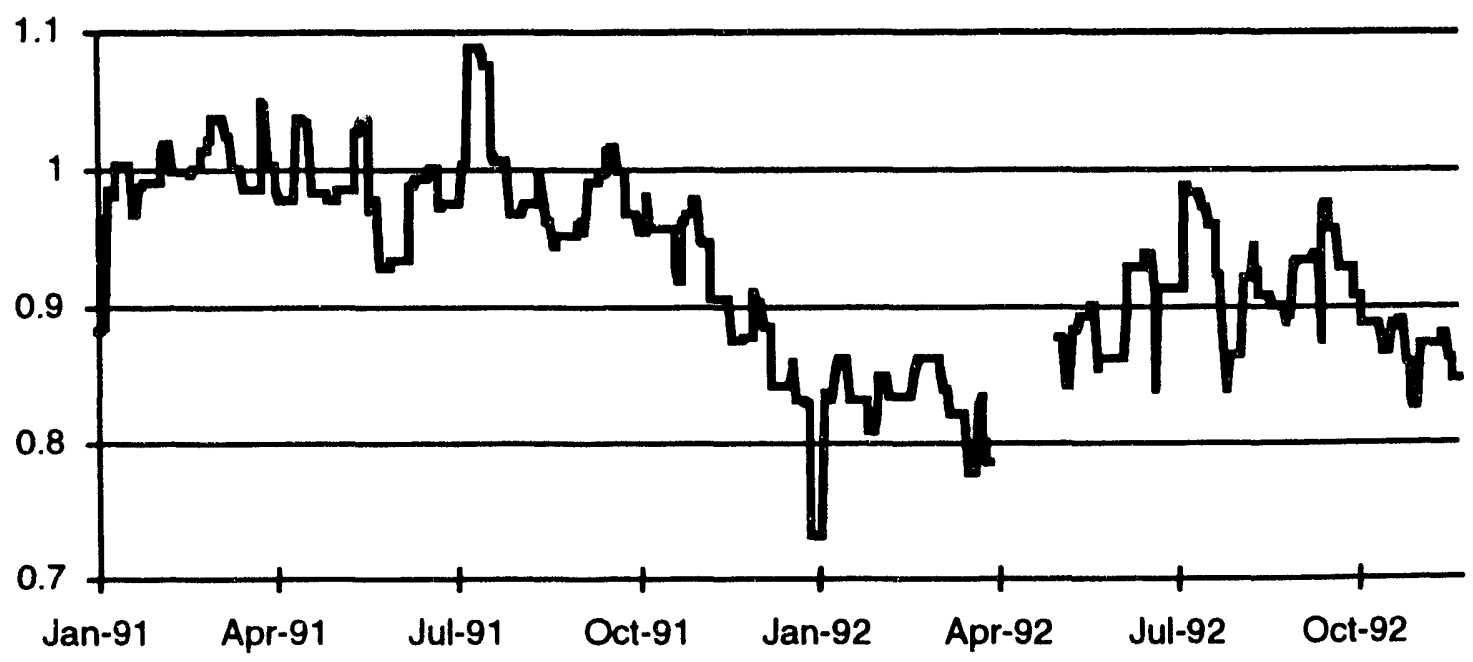

Figure S-2. Clear Sky DNI Quotients -- Golden, CO. 
As the figures illustrate, during the first half of 1991 DNI levels at both sites were comparable to those recorded in 1990 . The normalized ratios were approximately 1.0 at this time. Following the eruption in June 1991, a cyclic pattern of attenuation was seen: greater attenuation in the winter, less in the summer.

DNI levels at both sites during the winter of $1991 / 92$ were only $80 \%$ of their 1990 levels. This was followed by several months of decreasing attenuation. During the summer of 1992, DNI levels were within a few percent of their 1990 values. Attenuation again increased as the latter half of 1992 progressed. DNI levels in December 1992 were well below those of 1990 but were higher than recorded in 1991. 


\section{REFERENCES}

1. C. Joyce, "Volcano clouds the picture on global warming," New Scientist 131, 11 (1991).

2. R. A. Kerr, "Huge eruption may cool the globe," Science 252, 1780 (1991).

3. "Volcano could cool climate, reduce ozone," Science News 140, 7 (1991).

4. M. Iqbal, An Introduction to Solar Radiation, Academic Press, New York, 1983.

5. H.C. Hottel, "A Simple Method for Estimating the Transmittance of Direct Solar Radiation Through Clear Atmospheres," Solar Energy 18, 129 (1976). 
1606 Civil Engineering Squadron

Attn: James Fejer

1606 ABW/DEM

Deputy Chief, Operations Branch

Kirtland AFB, NM 87117-5496

3M-Energy Control Products (2)

Attn: R. Dahlen

P. Jaster

207-1W 3M Center

St. Paul, MN 55144

\section{M-Solar Optics Program}

Attn: Paul Jaster

Heather Kutzler

$3 \mathrm{M}$ Center

Bldg. 225-2n-06

St. Paul, MN 55144-1000

Advanced Thermal Systems

Attn: Dave Gorman

7600 East Arapahoe Rd., Suite 215

Englewood, CO 80112

Alabama Power Co.

Attn: Greg Reardon

P.O. Box 2641

Birmingham, AL 35291

Alabama Solar Energy Center

Attn: Leonard Adcock

University of Alabama in Huntsville

Huntsville, AL 35899

Alan Richardson

Business Liaison

New Postal Building

Room 3004

Santa Fe, NM 87501

American Institute of Architects

Attn: Richard C. Depta, AIA

Director Energy Information

1735 New York Ave., NW

Washington, DC 20006

Applied Concepts

Attn: S. Pond

2501 S. Larimer County Rd. 21

Berthound, CO 80513

Applied Research Associates, Inc. 4300 San Mateo NE, Suite A-220

Albuquerque, NM 87110
Aqua Vit Foundation

Attn: Rob Sangster

324 Wilkinson

Memphis, TN 38111

Argonne National Laboratory

Materials and Components Technology Div

Attn: Robert E. Holtz

9700 South Cass Avenue

Argonne, IL 60439

Arizona Department of Commerce

Arizona Energy Office

Attn: Jack Haenichen Frank P. Mancini, Ph.D.

3800 N. Central, Suite 1200

Phoenix, AZ 85012

Arizona Public Service Co.

Attn: Thomas C. Lepley

J. McGuirk

P.O. Box 53999

Phoenix, AZ 85072-3999

Ascension Technology

Attn: Ed Kern

Box 314

Lincoln Center, MA 01773

AT\&T

Attn: Gregory P. Robertson, P.E.

P. O. Box 13369

Phoenix, AZ 85002

Augustyn \& Company

Attn: Jim Augustyn

1029 Solano Ave., Suite C

Albany, CA 94706

B\&E Technical Services Inc.

Attn: William R. Lang

600 S. Cherry St. \#325

Denver, CO 80222-1705

Barber-Nichols Engineering

Attn: R. Barber

6325 West 55th Ave.

Arvada, CO 80002

Battelle Pacific Northwest Laboratory (2)

Attn: D. Brown

P.O. Box 999

Richland, WA 99352 
BDM Corporation

Attn: Tim Lanbarski

W. E. Schwinkendorf

MS-C35B

1801 Randolph Street, S.E.

Albuquerque, NM 87106

Bechtel National, Inc. (3)

Attn: P. DeLaquil

S. Nickovich

W. Stolte

50 Beale Street

50/15 D8

P.O. Box 3965

San Francisco, CA 94106

Black \& Veatch Consulting Engineers

Attn: J. C. Grosskreutz

P.O. Box 8405

Kansas City, MO 64114

Boston Edison Company

Attn: Michael Mulcahy

800 Boylston Street

Boston, MA 02199

Brookhaven National Labs

Attn: John Andrews

National Center for Analysis

of Energy Systems

Upton, NY 11973

Budd Company (The)

Attn: John M. Vergoz

3155 W. Big Beaver Road

Troy, MI 48084

Cal Tech

Attn: R. Middlebrook

116-81 Cal Tech

Pasadena, CA 91125

California Institute of Technology

Aeronautics Library

Attn: Jean Anderson

MS 205-45

Pasadena, CA 91125

California Polytechnic State University

Attn: Dr. Safwat M.A. Moustafa, P.E.

San Luis Obispo, CA 93407
California Polytechnic University

Dept. of Mechanical Engineering

Attn: W. B. Stine

Pomona, CA 91768-4062

Carlo LaPorta

2201 Wisconsin Avenue NE

Washington, DC 20007

Carolina Power \& Light Co.

Attn: Kent Hoffman

Center Plaza Bldg.

P.O. Box 1551

Raleigh, NC 27602

City of Albuquerque

Attn: Linda Stewart

City Council

P. O. Box 1293

Albuqueque, NM 87103

City of Albuquerque

Attn: Mike Minturn, Manager

Resource Managment Division

General Services Department

P. O. Box 1293

Albuquerque, NM 87013

City of Austin Power \& Light

Attn: David Panico

P.O. Box 1088

Austin, TX 78767

City of Las Cruces

Attn: Jerry Trojan

Assist. City Manager

P. O. Drawer CLC

Las Cruces, NM 88004

Clarkson University

Attn: Eric F. Thacher

Dept. of Mechanical and Aeronatucial Engrg.

Potsdam, NY 13699-5725

Colorado State University

Attn: Dr. Allan T. Kirkpatrick

Department of Mechanical Engineering

Ft. Collins, CO 80523

Colorado State University

Attn: Mark Thornbloom

Solar Energy Applications Lab

Fort Collins, CO 80523 
Commonwealth of Virginia

Department of Mines, Minerals, Energy

Attn: Susie Thomas

The Bookbinder Building

2201 West Broad St.

Richmond, VA 23220

County of Hawaii

Attn: Steve Burns

Dept. of Research and Development

25 Aupuni Street

Hilo, HI 96720

Cummins Engine Company

Attn: Dr. Isoroku Kubo

Mail Code 50179

Box 3005

Columbus, IN 47202-3005

Cummins Power Generation South

Attn: M. McGlaun

150 Tannehill Drive

Abilene, TX 79602

Cygnus Engineering

Attn: Vincent P. Dowd

R. D. 3, Box 2527

Middlebury, VT 05753

D\&T Solar

Attn: Thomas Caldwell

418 Vista Larga

Los Lunas, NM 87031

Dan Ka Products, Inc.

Attn: D. Sallis

3905 South Mariposa

Englewood, CO 80110

Datron Systems, Inc.

200 West Los Angeles Ave.

Simi Valley, CA 93065-1650

Dayton Power \& Light Comany

Attn: S. K. Aventsen

P. O. Box 1237

Courthouse Plaza

Dayton, $\mathrm{OH} 45401$

Dominion Energy Corp.

Attn: John Frank

P. O. Box 26532

Richmond, VA 23261
Don Beremand

30101 Wolf Rd.

Bay Village, $\mathrm{OH} 44140$

Dayton Power \& Light Company

Attn: S. K. Aventsen

P.O. Box 1247

Courthouse Plaza

Dayton, $\mathrm{OH} 45401$

Dominion Energy Corp.

Attn: John Frank

P.O. Box 26532

Richmond, VA 23261

Don Beremand

30101 Wolf Rd.

Bay Village, $\mathrm{OH} 44140$

Donnelly Corporation

Attn: M. DeVries

49 West Third Street

Holland, MI 49423

DSET

Attn: G. A. Zerlaut

Box 1850

Black Canyon Stage I

Phoenix, AZ 85029

\section{ECOTOPE}

Energy Efficient Solutions

Attn: David R. Baylon

2812 E. Madison

Seattle, WA 98112

Electric Power Research Inst.

Attn: E. DeMeo

J. Bigger

3412 Hillview Avenue

Palo Alto, CA 94303

Endecon

Attn: Chuck Whittaker

3401 Crown Canyon Road

Suite 253

San Ramon, CA 94583

Energy Concepts Co.

Attn: Don Erickson

627 Ridgely Ave.

Annapolis, MD 21401 
Energy System Consultants

Attn: Dana Sears

1532 79th Avenue NE

Brookland Park, MN 55444

Energy Technology Engr. Ctr.

Rockwell International Corp.

Attn W. L. Bigelow

P.O. Box 1449

Canoga Park, CA 91304

ENTECH, Inc.

Attn: M. O'Neill

R. Walters

P.O. Box 612246

DFW Airport, TX 75261

Environmental Laboratory

Attn: John A. Dufay

915 Locust St., NE

Albuquerque, NM 87106-4300

ESELCO

Attn: Sheldon L. Levy

8116 Fontana

Prairie Village, KS 66208

Eurodrive, Inc.

30599 San Antonio Rd.

Hayward, CA 94544

FAWP

Attn: Curtis H. Taylor 923 Old Bay Bridge Road

Tallahassee, FL 32303

Federal Conservation \& Renewable

Energy Referral Service

P. O. Box 8900

Silver Spring, MD 20907

Federal Energy Management Activities CE 10.1

U.S. Department of Energy

1000 Independence Ave.

Washington, DC 20585

Florida Power Corp.

Attn: Christy Herig

3201 34th Street South

St. Petersburg, FL 33711
Florida Power and Light

Attn: R. S. Allan

P.O. Box 14000

Juno Beach, FL 33408

Florida Solar Energy Center D(4)

Attn: John Harrison

Library

David Block

Jim Huggins

300 State Road 401

Cape Canaveral, FL 32920

Georgia Inst. of Technology

Attn: Sheldon Jeter

School of Mechanical Engineering

Atlanta, GA 30332

Georgia Power Co.

Attn: Dennis Keebaugh

W. King

7 Solar Circle

Shenandoah, GA 30265

Gould Inc., Foil Division

Attn: David C. Knipfer, Sr. Mech. Engineer

2929 W. Chandler Blvd.

P.O. Box 190

Chandler, AZ 85244-0190

Harris Corporation (2)

Government Aerospace Systems Division

Attn: K. Schumacher

P. O. Box 9400

Melbourne, FL 32902

Hawai'i Energy Extension Service

Attn: Andrea Gill Beck

Dept. of Business and Economic Development

Hawai'i Business Center

99 Aupuni Street \#214

Hilo, HI 96720

Hawaii Solar Energy Association

Attn: Ron Richmond

P. O. Box 23350

Honolulu, HI 96823

Heliodyne, Inc.

Attn: Jurg H. Bieri, Ph.D.

4910 Seaport Ave.

Richmond, CA 94804 
Hilda Frazier DCA

2740 Centerview Drive

Tallahassee, FL 32399-2100

Hydrogen Engineering Associates

Attn: Roy E. McAlister

540 North May St., Suite 3078

Mesa, AZ 85201

Industrial Solar Technologies

Attn: Randy Gee

5775 West 52nd Ave.

Denver, CO 80212

International Planning Association, Inc

Editor

807 Caddington Ave.

Silver Spring, MD 20901

Jacksonville Electric Authority

Attn: George Rizk

Box 53105

Jacksonville, FL 32201

Jet Propulsion Laboratory

Attn: M. Alper

4800 Oak Grove Drive

Pasadena, CA 91109

Kearney \& Associates

Attn: David W. Kearney

14022 Condessa Drive

Del Mar, CA 92014

Kirk Enterprises, Inc.

Kirkland \& Richards Solar \& Elect.

Attn: Gregory H. Kirkland

P.O. Box 741

Inglis, FL 32649

Long Island Lighting Co.

Attn: Joseph Miller

175 E. Old Country Road

Hicksville, NY 11801

Los Alamos National Laboratory

Attn: Dr. Donald Neeper

Staff Member

Advanced Engineering Technology Group

P.O. Box 1663, MS F576

Los Alamos, NM 87545
Lower Colorado River Resource

Conservation \& Development Project

Attn: Michael Forrest

Coordinator

1713 Kofa, Suite G

Parker, AZ 85344

Massachusetts Institute of Technology

Attn: J. G. Kassalkian

M. F. Schlect

Elec. Power Systems Engr. Lab.

Cambridge, MA 02139

Mechanical Technology, Inc.

Attn: G. R. Dochat

968 Albany Shaker Road

Latham, NY 12110

Meridian Corporation (2)

Attn: D. Kumar Anil Cabraal

4300 King Street, Suite 400

Alexandria, VA 22302-1508

MicroGrid, Inc.

Attn: Terry L. Egnor

500 N.E. Multnomah, Suite 1050

Portland, OR 97232

Midwest Research Institute

Attn: $\quad$ R. L. Martin

425 Volker Blvd.

Kansas City, MO 64110

NASA/Lewis Research Center

Attn: R. Corrigan Richard DeLombard

21000 Brookpark Road

Cleveland, $\mathrm{OH} 44135$

National Renewable Energy Lab (5)

Attn: James G. Jones

Russ Hewett

T. Williams

L. M. Murphy

Steve Rubin

1617 Cole Blvd.

Golden, CO 80401-3393

National Technology Transfer Center

Attn: Sergio Lopes

Wheeling Jesuit College

Wheeling, WV 26003 
Natural Power, Inc.

Attn: Brian Gordon

Francestown Turnpike

New Boston, NH 03070

Nature Conservancy

Attn: Will Murray

1815 N. Lynn Street

Arlington, VA 22209

Naval Civil Engineering Lab

Attn: Kwang Ta Huang

CODE L 72

Port Hueneme, CA 93043

Nebraska Department of Economic Development

Attn: Rex Martin

University of Nebraska-Lincoln

W191 Nebraska Hall

Lincoln, NE 68588-0535

New England Power Service

Attn: Ed Gulachenski

25 Research Drive

Westborough, MA 01581

New Mexico Electric Cooperative

Attn: Robert E. Castillo

Executive Vice President

614 Don Gaspar

Santa Fe, NM 87501

New Mexico Institute of Mining \& Technology

Attn: Joe Galon

Associate Director of Engineering

Physical Plant Department

Campus Station

Socorro, NM 87801

New Mexico League of Women Voters

Attn: Barbara M. Rosnagle

Natural Resources Chair

116 Salamanca, N.W.

Albuquerque, NM 87107

New Mexico Manufacturing Productivity Center

Attn: Graham Bartlett

1009 Bradbury Drive, S.E.

Albuquerque, NM 87106

New Mexico Public Service Commission

Attn: Peter Bickley

224 E. Palace Avenue

Santa Fe, NM 87501-2031
New Mexico R\&D Forum

University of New Mexico

Attn: Richard Cole

Director

R\&D Communication Office

Albuquerque, NM 87131-6076

New Mexico Energy Industries Association

Attn: Tom Volek

P.O. Box 90275

Albuqurque, NM 87199-02175

New Mexico Solar Energy Institute

New Mexico State University

Box 3 SOL

Las Cruces, NM 88003

New Mexico State University

Attn: Nick Deveraux

Astronomy Department

Box 30001, Dept. 4500

Las Cruces, NM 88003

New Mexico State University

Attn: Pat Melendrez

San Miguel County Extension Agent

P.O. Box 2170, West Branch

Las Vegas, NM 87701

New Mexico State University (3)

Southwest Technology Development Institute

Attn: Steve Durand

Andrew L. Rosenthal

Dr. Rudi Schoenmackers

Box 30001, Dept. 3SOL

Las Cruces, NM 88003-0001

New Mexico State Unversity

Cooperative Extension Service

Attn: Rob ert O. Coppedge, Ph.D.

Box $3 \mathrm{AE}$

Las Cruces, NM 88003

New York State Energy Research and Dev. Authority

Attn: Fred Strnisa

2 Rockefeller Plaza

Albany, NY 12223

New York State Pub. Serv. Comm.

Attn: Edward Schrom

Empire State Plaza

Albany, NY 12223 
Nippon Electric Glass Co., Ltd.

Attn: Bernard L. Steierman

11801 Rockville Pike, Suite 1704

Rockville, MD 20852

North Carolina Alternative

Energy Corp.

Attn: Bob Weiss

P.O. Box 12699

Research Triangle Park, NC 27709

Northern Research \& Eng. Corp

Attn: Dr. James B. Kesseli

39 Olympia Avenue

Woburn, MA 01801-2073

Northwest Power Planning Council

Attn: Tom Truelove

851 S.W. Sixth Ave., Suite 1100

Portland, Oregon 97204

Pacific Gas and Electric Co. (4)

Attn: Steve Hester

G. Braun

3400 Crow Canyon Road

San Ramon, CA 94583

Parsons of Califomia

Attn: $\quad$ D. R. Biddle

P.O. Box 6189

Stockton, CA 95206

Pennsylvania Energy Office

Attn: Dr. Phillip Schuller, Associate Director

116 Pine Street

Harrisburg, PA 17101-1227

Photovoltaic Energy Systems

Attn: Paul Maycock

P. O. Box 290

Casanova, VA 22017

Platte River Power Authority

Attn: Carol Dollard

Timberline, and Horsetooth Roads

Fort Collins, CO 80525

Portland State University

Attn: Jean P. Murray, Ph.D.

P.O. Box 751

Portland, OR 97207-0751
Power Kinetics, Inc.

Attn: W. E. Rogers

415 River Street

Troy, NY 12180-2822

Public Service Co. of New Mexico

Attn: Becky Kilbourne

Retail Electric Marketing Center

Alvarado Square

Albuquerque, NM 87158

Public Service Co. of New Mexico

Attn: Vic Silva

CR Dept. (0076)

Alvarado Square

Albuquerque, NM 87158

Radco Products, Inc.

Attn: George O. Radford

President

2877 Industrial Parkway

Santa Maria, CA 93455

Renewable Energy Institute

Attn: Kevin Porter

1001 Connecticut Avenue NW

Suite 719

Washington, DC 20036

Research Triangle Institute

Attn: Carl Parker

P.O. Box 12194

Research Triangle Park, NC 27709

Roan Corporation

Attn: James L. Abolt

177 Bovet Road, Suite 520

San Mateo, CA 94402

Rockwell International Corporation

Energy Technology Engineering Center

Attn: Robert K. Hoside, C.E.M.

P. O. Box 1449

Canoga Park, CA 91304

Rockwell International

Space Station Systems Division

Attn: I. M. Chen

12214 Lakewood Blvd.

Downey, CA 90241 
San Diego Gas \& Electric Co.

Attn: Skip Fralick

P.O. Box 1831

San Diego, CA 92112

\section{Schofield Solar}

Attn: Allen Carrozza

2450 Channel Drive, Suite A

Venture. CA 93003

Science and Technology Corporation

Attn: Ronald J. Nelson

12452 Towner, N.E.

Albuquerque, NM 87112

Science Applications International Corp.

Attn: Barry Butler

Mail Stop 32

10260 Campus Point Court

San Diego, CA 92121

Scientific Analysis, Inc.

Attn: John Allen Gunn, PE

6012 E. Shirley Lane

Montgomery, AL 36117

Seldom Seen Education

Attn: Mary C. Stuever

P.O. Box 474

Placitas, NM 87043

Sierra Club Rio Grande Chapter

Attn: Ken Hughes Energy Chair]

1204 Placita Loma

Santa Fe, NM 87520

Sierra Pacific Power Co.

Attn: R. G. Richards

P. O. Box 10100

Reno, NV 89520

SMUD

Attn: Don Osborne

Box 15830

Sacramento, CA 95852-1830

Solar Development, Inc.

Attn: David Burrows

3630 Reese Avenue

Garden Industrial Park

Riviera Beach, FL 33404
Solar Energy Corporation

Attn: Robert Aresty

Box 3065

Princeton, NJ 08540

Solar Energy Industries Association

Attn: Ken Sheinkopf

S. Sklar

Linda Ladas

777 N. Capitol St., N.E., Suite 805

Washington, DC 20002-4226]

Solar Kinetics, Inc.

Attn: J. A. Hutchison

P.O. Box 540636

Dallas, TX 75354-0636

Solar Power Engineering Co. Inc.

Attn: T. Buna

P. O. Box 91

H. Wroton

Morrison, CO 80468

Solar Steam

Attn: D. E. Wood

P.O. Box 32

Fox Island, WA 98333

Southern California Edison Co.

Attn: C. Lopez

P.O. Box 800

Rosemead, CA 91770

Southern Company Services, Inc.

Attn: J. Timothy Petty

P.O. Box 2625

Birmingham, AL 35202

Southwest Technology Development Institute

Attn: Robert Smith, M.E.

Property Control Division

General Services Department

Simms Building

715 Alta Vista

Santa Fe, NM 87503

SRS Technologies

Attn: R. Bradford

990 Explorer Blvd., NW

Huntsville, AL 35806 
State of California

California Energy Commission

Energy Technology Development Division

Research and Development Office

Attn: Promod Kul.ami

Phil Misemer

1516 9th Street, MS-43

Sacramento, CA $95814-5512$

State of California

California Energy Commission

Attn: Alec Jenkins

1516 - 9th Street

Sacramento, CA $95814-5512$

State of California

Department of Corrections

Attn: Harry Franey

3116 Pleasant Grove Road

Pleasant Grove, CA 95668

State of Colorado

Office of Energy : 'nnservation

Attn: Howard "Andy" Walker, Ph.D , M.E. Renewable Energies Coordinator

1675 Broadway, Suite 1300

Denver, CO 80202-4613

State of Florida

Attn: Daryl O'Connor

Executive Office of the Governor

The Capitol

Tallahassee, FL 32399-0001

State of Florida

Colleen McCann Kettles

Attn: David Block

Jim Huggins

Florida Solar Energy Center

300 State Road 401

Cape Canaveral, FL 32920-4099

State of Hawaii

Attn: David A. Rezachek, Ph.D., P.E.

Maurice H. Kaya, P.E.

Dept. of Business and Economic Development 335 Merchant St.

Honolulu, HI 96813
State of New Mexico

Energy Information Services

Energy, Minerals and Natural Resources Dept.

Attm: Ingrid Kelley

2040 South Pacheco Street

Santa Fe, NM 87505

State of New Mexico

Energy, Minerals and Natural Resources Dept.

Attn: James Cannon

Anita Lockwood

Harold Trujillo]

Brian K. Johnson, P.E.

2040 South Pacheco Street

Santa Fe, NM 87505

State of New Mexico

Energy, Minerals and Natural Resources Dept.

Attn: Judy Kowalski Director of Recycling Programs

2040 South Pacheco Street

Santa Fe, NM 87505

State University of New York

Atmospheric Sciences Research Center

Attn: R. Perey

Albany, NY 12222

State of Texas

Department of Commerce

Attn: Charles Nichols

Renewable Energy Market

Development Specialist

Office of Advanced Technology

P.O. Box 12728

Austin, TX 78711

Sterling Grogan, Ecologist

3128-2 Glenwood Drive

Albuquerque, NM 87107

Stearns-Catalytic Corp.

Attn: T. E. Olson

Box 5888

Denver, CO 80217

Sun Expl tation and Production Co.

Attn: R. I. Benner

P.O. Box 2880

Dallas, TX 75221-2880 
Sun Utility Network, Inc.

Attn: Les Hamasaki

510 W. 6th St., Suite 417

Los Angeles, CA 90014

Sunshine Solar, Inc.

Attn: Steven R. Robbins, President

9916 SW 218 Terr.

Miami, FL 33190

Technology Enterprise Division

Attn: Karen Martin

P. O. Box 549

Mesilla, NM 88046

Tennassee Valley Authority

Attn: Sharon Ogle

Solar Applications Branch

B 513 Signal Place

Chattanooga, TN 37401

The Amorial Bearings of Tuthill

Education/Development

Attn: Jerry Tuttle, Ph.D.

12305 Eastridge Drive, N.E.

Albuquerque, NM 87112

The Energy Foundation

Attn: Bill Keepin

75 Federal Street

San Francisco, CA 94107

The Solar Letter

Attn: Allan L. Frank

9124 Bradford Rd.

Silver Spring, MD 20901-4918

Thermomotor Corporation

Attn: Lee Fellows

Stirling Engine Research \& Devalopment

P. O. Box 201207

Austin, TX 78720

Tom Brumleve

1512 Northgate Road

Walnut Creek, CA 94598

U.S. Army Corps of Engineers

Attn: Larry D. Lister

P.O. Box 4005

Mechanical Engineer

Champaign, IL 61720-1305
U.S. Army Engineering and Housing

Support Center

Attn: Rober G. O'Brien, P.E.

CEHSC-FU

Chief Utilities Engineering Division

Fort Belvoir, VA 22060-5580

U.S. Department of Energy (4)

Forrestal Building

Attn: G. Burch

N. Hough

S. Gronich

Code EE-13

C. Carwile

1000 Independence Avenue, SW

Washington, DC 20585

U.S. Department of Energy

San Francisco Operations Office

Attn: R. Hughey

1333 Broadway

Oakland, CA 94612

U.S. Department of Energy

Forrestal Building

Attn: R. Annan

Code EE-13

1000 Independenc Avenue, SW

Washington, DC 20585

U.S. Department of Energy (2)

Albuquerque Operations Offices

Attn: N. Lackey

P. O. Box 5400

Albuquerque, NM 8715

Unique Mobility Inc.

Attn: William M. Anderson

3700 South Jason St.

Englewood, CO 80110

United Solar Technologies, Inc.

Attn: Richard Kelly

3434 Martin Way, Suite One

Olympia, WA 98506

University of Chicago

Enrico Fermi Institute

Attn: J. O'Gallagher

5640 Ellis Avenue

Chicago, IL 60637 
University of Central Florida

Atm: Dr. Gerard G. Ventre

Research Scientist

Institute for Simulation and Training

12324 Research Parkway, Suite 300

Orland, FL 32826

University of Delaware

Attn: Allen Bamett

Dept. of EE

Newark, DE 19711

University of Hawaii

Attn: Patrick Takahashi

Hawaii Natural Energy Inst.

2540 Dole Street

Honolulu, HI 96822

University of Lowell

Attn: Thomas Costello

Fahd Wakim

1 University Avenue

Lowell, MA 01854

University of Nevada at Las Vegas

Attn: B. Boehm

Mechanical Engineering Department

Las Vegas, NM 89154

University of New Mexico

NMREI

Attn: G. Leigh

Albuquerque, NM 87131

University of New Mexico

Attn: M. W. Wildin

Department of Mechanical Engineering

Albuquerque, NM 87131

USAF/ETAC

Attn: Hilda Snelling

ENGRC Meteorology Section

Scott AFB, IL 62225

Ventures Plus, Inc.

Attn: Frank A. Simko

4123 N. Tamiami Trail

Sarasota, Fl 34234
Virginia Polytechnic Inst. and State University

Attn: Saifur Rahman, Ph.D.

Associate Professor

Electrical Engineering Department

Blacksburg, VA 24061

Wall Street Jounral

Attn: David Stipp, Environmental reporter

10 Post Office Square

Suite 715

Boston, MA 02109

Westinghouse Science \& Tech. Ctr.

Attn: Walter J. Dollard Technology Director

Energy \& Utility Systems Group

1310 Buelah Rd.

Pittsburg, PA 15235

Zomeworks

1011A Sawmill Road, N.W.

Albuquerque, NM 87104

\section{FOREIGN}

Australian National University

Department of Engineering Physics

Attn: Prof. Stephen Kaneff

P.O. Box 4

Canberra ACT 2600, AUSTRALIA

DLR

Institute for Technical Thermodynamics

Attn: R. Buck

Pfaffenwaldring 38-40

7000 Stuttgart 80, GERMANY

Energy Research Centre (2)

Attn: $\quad K$. Inall

R. S. Phy. Sc.

Australian National University

Canberra ACT 2601

AUSTRALIA

Intermal Distribution

4212 M. Allen

4212 R. Hamil

4212 D. Belasich 
C. Lombawa

6000

D. L. Hartley

6200 D. E. Arvizu

6200 A. VanArsdall

6201 P. C. Klimas

6202 G. J. Jones

6213 T. C. Bickel

6215 C. P. Cameron

6215 R. M. Edgar

6215 M. E. Ralph

6215 E. E. Rush

6215 J. W. Strachan

6216 C. E. Tyner

6216 J. R. Anderson

6216 L. R. Evans

6216 T. R. Mancini

6216 D. F. Menicucci (20)

6218 D. E. Hasti

6218 R. R. Hill

6218 R. C. Pate

6218 H. N. Post

6218 J. W. Stevens

7141 S. A. Landenberger (5)

Document Processing DOE/OSTI (8)

R. Wrons

8523 Central Technical Files 

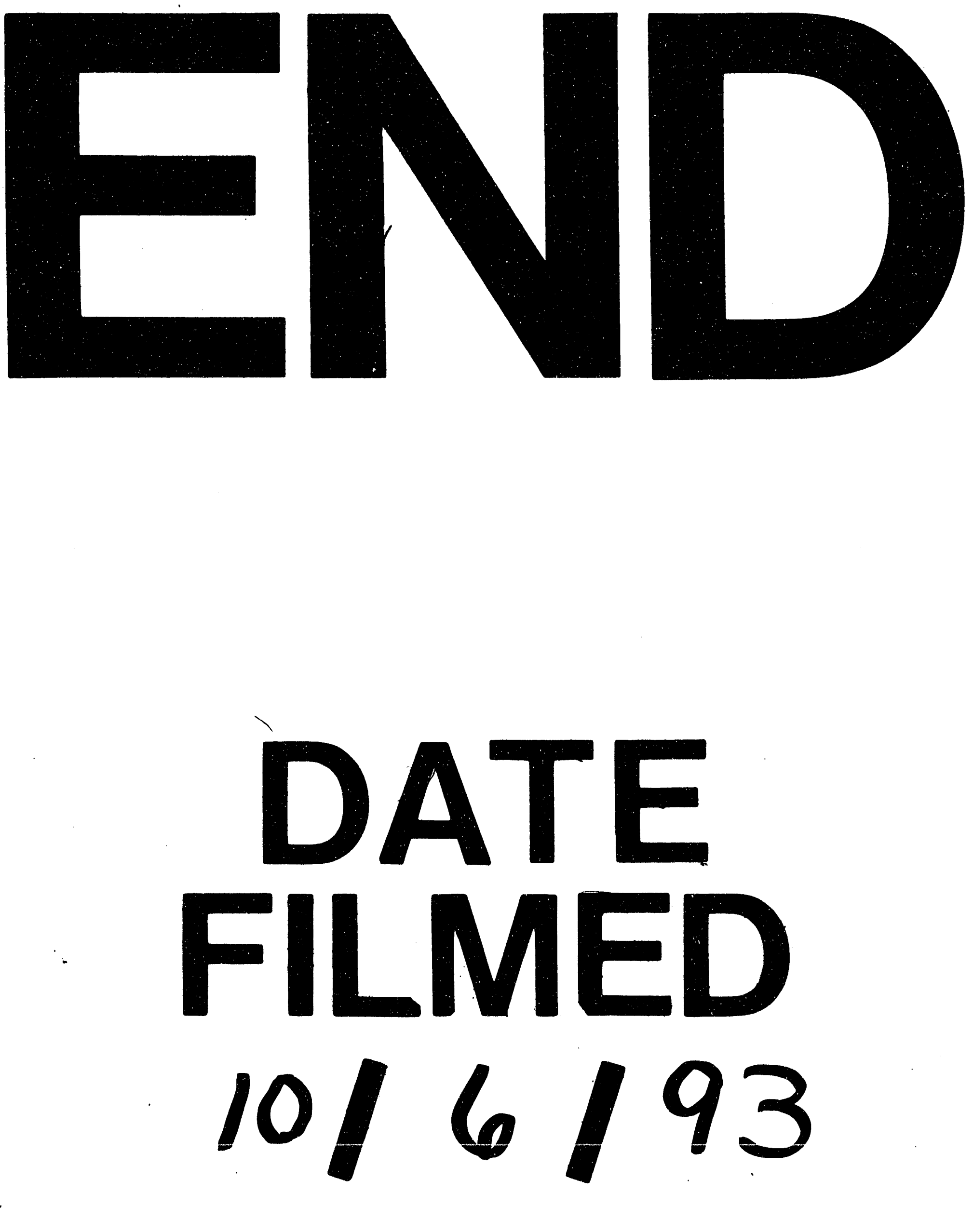

1 
